\title{
발표논문
}

\section{中国佛教考古学的调查 发掘与研究}

龚国强 || 中國社會科學院考古䂰究所

佛教自东汉传入中国以后，经过汉至三国两晋时期佛教输入和模仿的第 一阶段以后, 在北朝一唐代时期进入了快速发展、改造和逐步中国化的阶段, 至宋元明清时期佛教已经完全本地化。佛教在中国的发展，除了其在印度传 统佛教思想的基础上，根据中国本地国情适应和调整的内在原因外，还在于 自东晋以后争取到了历代统治者及其广大民众大力支持的外在因素，故此发 展迅速，不仅可与中国本地产生的道教分庭抗礼，很多时期甚至还压过一 头，以至佛寺佛塔在全国遍地开花，到处可见，并且规模等级不断提高，几 可比拟于皇宫建筑，同时，僧尼人众不断扩大，势力得到空前的壮大，从而 对中国各时期社会政治、经济、文化艺术等各个方面造成了重大的历史影 响, 成为国内外学术界的重要研究对象。

佛教在发展过程中，佛教建筑和佛教艺术作品等是佛教思想传播和阐释的 重要实物媒介, 发挥了不可替代的重要作用。经过千百年的洗礼, 中国大地 上留下了大量的佛教寺庙、佛塔、石窟、佛教雕塑和壁画、佛教文献、佛教 用品等遗迹遗物。因此，佛教考古学调查、发掘和研究，已经成为中国考古 学的重要组成部分和重要分支学科。

.中国佛教考古是以佛教遗迹遗物为研究对象的考古学分支, 主要分石窟 寺、平地和山地佛寺两大部分，其中包括与两者密切相爸的造像、壁画、碑 
刻、经幢、佛教用品等等，涉及到古代历史、古代建筑史、美术史、哲学宗 教史、古代文献学、民族学、科技考古、中外文化交流史等诸多研究科目。 目前，中国石窟寺考古研究较为系统和独立，成果丰富，蔚为大观，而平地 和山地佛寺遗址的考古研究则相对比较薄弱，尚需要进一步发展和提高。

下面，我将从中国佛教考古学调查和发掘回顾、主要研究课题、以及问 题和展望等三个方面进行简要论述, 诚新学界同仁指导和批评。

\section{(一)、石窟寺考古調査和發掘}

中国佛教石窟洲源于印度，始業于公元三世纪，兴盛于五至八世纪，直到 十六世纪时尚有丵建，其形制种类大致分有中心塔柱的塔庙窟、无中心塔柱的 佛殿窟、僧房窟、雕塑大型佛像的大像窟、内设坛像的佛坛窟、小型禅窟等 ${ }^{1)}$ 。

对中国石窟寺的考古调查，始于二十世纪初及解放前国外学者的探险调查 和发掘。自1893年至1931年，英国斯坦因、德国格伦威德尔和勒柯克、法国 伯希和、瑞典的喜龙仁、美国的华尔纳等纷纷来到中国西北地区，考察了新 疆、内蒙、甘肃等地的一些佛寺和石窟，如尼雅、楼兰、米兰、丹丹乌里 克、热瓦克、库车苏巴什、杜尔杜尔 -乌库尔、图木休克、七个星、克孜 尔、伯孜克里克、敦煌、黑河等地的佛塔和佛寺遗址，带走了大量的佛教雕 塑、壁画、文书等佛教遗物。这些资料都在西方出版，其中最著名的有斯坦 因《古代和阗》(1907年)、《亚洲腹地考古记)(1928年)、《西域考古记》 (1921年)、伯希和《伯希和西域探险记》、勒柯克的《高昌图录》等, 引起 了西方学者对中国佛教遗迹和遗物的研究热潮。

日本学者也不甘落后，1902－1914年间，大谷光瑞、橘瑞超，调查和发掘 
了吐魯番、楼兰、库车、和田等地的佛寺遗址等，收集了大量的珍贵文物。 1918－1924年间，常盘大定、爸野贞对中国各地地佛教遗址进行了调查， 随后于1925－1939年间陆续出版《支那文化史迹》、《支那佛教史迹》、 《支那佛教史迹踏查记》等书。1938-1941年, 水野清一、长广敏雄等赴中 国进行调查并发掘后, 于1941年出版《响堂山石窟》, 1951年发表出版《云 冈石窟》16卷。

中国学者也相应地开展了一些调查。1918 年, 中国学者陈垣较系统地考 察和考证了云冈石窟，后发表《记大同武州山石窟寺》。1932年，中国营造 学社梁思成、刘敦桢等调查云冈石窟, 后发表《云冈石窟所表现的北魏建 筑》等文。

1949年新中国成立至1969年，中国石窟寺考古进入了草创时期。北京大学 考古专业阎文儒、宿白等教授率先开展了有炃石窟寺考古地教学, 培训了一 批从事石窟寺考古的研究人才和领军人物。同时，敦煌莫高窟、云冈、龙 门、克孜尔、响堂山、麦积山等各重要石窟寺所在地相继成立了研究院、研 究所、保管所, 开展了全面的考古调查(包括测量、著录)、发掘和研究工 作。新发现甘肃永靖炳灵寺、武威天梯山、庆阳北以及陕西地区的石窟寺 等。1957和1961年, 北京大学考古专业到响堂山和敦煌石窟开展了教学实 习。1957年, 北京大学宿白教授在敦煌文物研究所作《敦煌七讲》讲座, 开 创性地将考古学方法引入到石窟寺调查和研究中, 标志着中国石窟寺考古的 正式诞生。

1970年以后至今, 中国石窟寺考古进入了发展和繁荣时期, 各地运用考古 学方法对石窟寺进行清理发掘、调查实测和综合研究，都取得了重大的进展）。

1979 -1981年，在宿白先生率领北京大学历史系石窟考古实习组，对新 疆克孜尔石窟逐个调查、记录、实测, 并对部分洞窟进行挖掘和清理, 取 得了重大突破。1997年整理出版了《新疆克孜尔石窟考古报告》。是目前出 版的第一本石窟寺考古报告。 
1980年以后，北京大学考古学专业又陆续在宁夏固原须弥山石窟、河北邯 郸南响堂石窟、河西走廊的早期石窟、龙门石窟、麦积山石窟的部分洞窟进 行了一些测绘和调查工作。

1988一1995年，继60年代对南区殿堂遗址的发掘，敦煌研究院对极为重要 且又被长期忽视的敦煌莫高窟北区洞窟 243 个洞窟进行了全面清理和发掘，对 北区洞窟的性质和内涵有了新的认识，区分出僧房窟、禅窟(单室和多室)、 僧房窟附设禅窟、座窟、礼佛窟和等形制, 洞窟开丵以中段为早, 以后陆续 向两侧开業。发掘揭示了北区洞窟是供僧众生前生活、居住、禅修之地和死 后座埋之所的性质，其时代从北朝一直延续到元代。2000 年、2004年相继出 版了《敦煌莫高窟北区石窟》第1、2、3卷。

1989一1990年，新疆文物部门对克孜尔石窟谷西区部分洞窟的窟前遗址进 行发掘清理，新发现洞窟30余个，且一些洞窟有打破矢系，对克孜尔石窟的 时代划分有重要的价值。

1994年, 云冈石窟保管所对云冈石窟窟前遗址作了部分清理发掘, 出土了 一批贴金佛像残块和 4 处建筑遗址。

2002-2006年，中国科学院考古研究所和山西省文物部门联合组成考古 队，在太原西南龙山北蜂上，对创建于北齐、兴盛于唐代的的童子寺遗址进 行了多次发掘。清理出院落、月台、大殿、佛台、经幢、僧房等遗迹，大殿

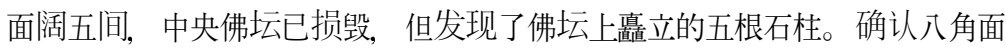
体石刻经幢身和幢顶为唐代遗物。近年来还调查发现了大佛石像。

1999年，在新疆库车县70公里的克孜里亚大峡谷中新发现了一处孤存的阿 艾石窟，内有壁画、汉文题记等 ${ }^{3)}$ 。

2008年, 洛阳龙门石窟研究院与北京大学文博学院联合对龙门石窟擂鼓 台窟前区域进行了考古发掘，发现唐代窟前踏道、窟前殿堂包石台基、宋代 造像题记和建筑基础、唐宋时期窟前道路等遗迹现象。

解放以后, 石窟寺考古的发展还体现在了《敦煌研究》、《敦煌学辑 
刊》、《圷鲁番学研究》、《石窟寺研究》等学术刊物的创立, 为广大学 人提供了发表专业论文的平台。同时，许多图录、资料集、论文集、论著 等也纷纷出版。首先当推，宿白先生1996年出版的经典著作《中国石窟寺研 究》, 2010年《中国佛教石窟寺遗迹: 3至8世纪中国佛教考古学》一书出 版。从1980年12月开始，日本平凡社、中国文物出版社合作，在北京和东京 两地陆续出版《中国石窟》中日两种文版, 共17卷, 依次为: 《敦煌莫高 窟》5 卷, 《讯县石窟寺》 1 卷, 《克孜尔石窟》 3 怣, 《库木吐石窟》 1 卷, 《永端炳灵寺》1卷, 《夭水麦积山》1卷, 《龙门石窟》2 卷, 《云冈石 窟》2卷，《安西榆林窟》1卷。每参发表图版192 300幅,论文2 5篇, 并 有图版说明、大事年表和实测图, 还发表各石窟群的内容总录。另外, 《中国美术分类全集》、《中国壁画全集》、《徽煌莫高窟内容总录》、 《龙门石窟总录》、《须弥山石窟内容总录》、《敦煌石窟全集》、《俄 罗斯国立艾尔米塔什博物馆藏敦煌艺术品》等得以出版发行, 推进了有爸的 学术研究。

另外，一些大型的国际学术研讨会也时有召开，事后多出版了会议论文 集：《1994 年敦煌学国际讨论会文集. 石窟考古编》(甘肃民族出版社 2000 年)、龙门石窟一千五百周年国际学术讨论会论文集》 (文物出版社出版 1996-年出版)、《炳灵寺石窟学术研讨会论文集》(由甘肃人民出版社2003年 10月出版、

《2004年石窟研究国际学术会议论文集》(上、下册)(上海古籍出版社 2006年出版)、《云冈石窟国际学术研讨会论文集》(保护卷、研究然)(文物 出版社2006年出版)等。

此外, 敦煌研究院编《敦煌研究文集. 敦煌石窟考古篇》, 甘肃民族出版 社,2000 年由兰州大学敦煌学研究所、麦积山石窟艺术研究所所编的《天水 麦积山石窟研究论文集》、兰州大学敦煌学研究所编《永端炳灵寺石窟研究 文集》等论文集也得以出版。 
上述诸多图录、学术论集的出版，一定程度上反映了中国石窟寺考古研究 的广度和深度。

\section{(二)、平地和山地佛寺遺址的考古調査和發掘}

如上所述，二十世纪初，西方和日本探险家首先在中国新疆等地佛寺遗址 进行了调查和发掘。

较早对中国佛寺遗址进行调查的中国学者首推黄文顼，他曾于1927年、 1930年、1943年三次考察了新疆塔里木盆地等地的佛寺遗址，后出版有《罗 布淖尔考古记》(1948)、《吐鲁番考古记》(1954、1958)、《塔里木盆地考 古记》(科学出版社1958年)、《西北史地论丛》等书。

1937年，建筑学家梁思成和林徽因、莫宗江等人赴山西五台山调查，发现 了唐代的佛光寺大殿。同时, 梁思成和刘敦桢带领研究人员, 调查了云南、 四川等地 40 余个县的古佛寺等古代建筑，绘制了大量古建筑模型图，在营造 学社的汇刊上发表了《我所知道的唐代佛寺与宫殿》、《蓟县独乐寺山门 考》、《云岗石窟中所表现的北魏建筑》等论文。1944年, 梁思成开始撰写 《中国建筑史》。

新中国成立以后，平地和山地佛寺的考古工作虽然比较零散，但一直有持 续不断的发现和发掘，有些还产生了重要的社会影响。下面主要按地区和时 代顺序进行叙述。 


\section{1、中原地區}

（1）佛寺塔基地宫、塔内天宫的考古发现

自1964年以来，各省市均不断发现有佛寺塔基地宫、塔内天宫，出土㓐埋 舍利的器具及供养品等，大都具有明确的纪年。具体见下表(依地区顺序)。

\begin{tabular}{|c|c|c|c|c|c|}
\hline 序号 & 發現地点 & 發現時間 & 出土主要遺迹 遺物 & 年代 & 備注 \\
\hline 1 & 河北定縣城塔基 & 1964年 & $\begin{array}{l}\text { 石函、琉璃鉢、銅鉢和琉缡葫芦瓶、七宝飾物 } \\
\text { 珠宝 }\end{array}$ & 北魏 481年 & (考古) 66.5 \\
\hline 2 & $\begin{array}{c}\text { 河南洛陽北永宁 } \\
\text { 寺塔基 }\end{array}$ & 1979 & 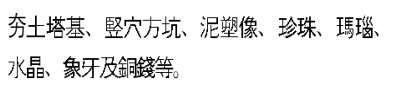 & $\begin{array}{c}\text { 北魏熙平元年 } \\
\text { (526年) }\end{array}$ & 〈考古〉 81.3 \\
\hline 3 & $\begin{array}{l}\text { 陕西西安東效毒 } \\
\text { 福寺倩舍利墓 }\end{array}$ & 1986 & 墓志 灰陶耯、供養珠宝飾物 & $\begin{array}{c}\text { 大隋開皇9年( } \\
589 \text { 年 })\end{array}$ & 《考古与文物》 88.1 \\
\hline 4 & $\begin{array}{l}\text { 山東平陰倩舍利 } \\
\text { 宝塔石函 }\end{array}$ & 1982 & 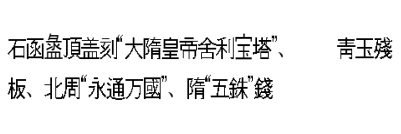 & $\begin{array}{c}\text { 隋文帝仁壽年 } \\
\text { 間 } \\
\text { (601 604年) }\end{array}$ & (考古) 86.4 \\
\hline 5 & $\begin{array}{l}\text { 陕西糔隋神德寺 } \\
\text { 舍利塔基 }\end{array}$ & 1969 & 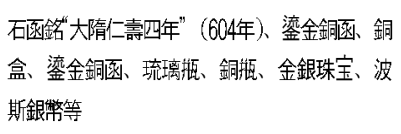 & 隋代 & (栲古) 74.2 \\
\hline 6 & $\begin{array}{l}\text { 山西太原龍泉寺 } \\
\text { 塔基地宮 }\end{array}$ & 2008 & 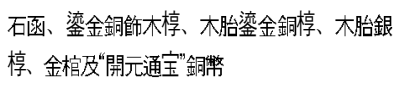 & 武居時期 & $\begin{array}{c}2008 \\
\text { 中國重要考古發現 }\end{array}$ \\
\hline 7 & $\begin{array}{l}\text { 四川成都唐代塔 } \\
\text { 基地宮 }\end{array}$ & 1980 & 石函、鈳棺、銀壦、“五銖”錢 & 唐代 & 《考古与文物》 83.3 \\
\hline 8 & $\begin{array}{l}\text { 江蘇句容行香朱 } \\
\text { 隍村唐代塔基 }\end{array}$ & 1975 & 地宮、鐵函、銅楟、銀亭、小鉰棺 & 唐代早期 & (考古) 82.2 \\
\hline 9 & $\begin{array}{l}\text { 甘肅涇川唐代大 } \\
\text { 云寺塔基地宮 }\end{array}$ & 1964 & 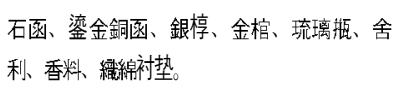 & 武周時期 & (文物) 66.3 \\
\hline 10 & $\begin{array}{c}\text { 陕西周至縣仙游 } \\
\text { 寺法王塔 }\end{array}$ & 1988 & 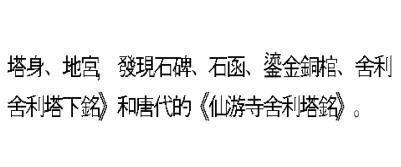 & 唐代 & $\begin{array}{c}\text { 仙游寺隋唐塔銘 } \\
\text { 兩种 } \\
\text { 王其神，陕西人民 } \\
\text { 出版社05年 }\end{array}$ \\
\hline
\end{tabular}




\begin{tabular}{|c|c|c|c|c|c|}
\hline 序号 & 發現地点 & 發現時間 & 出土主要遺迶 遺物 & 年代 & 備注 \\
\hline 11 & $\begin{array}{l}\text { 河南登封法王寺 } \\
\text { 塔基地宮 }\end{array}$ & & 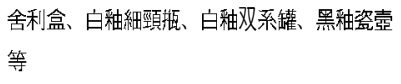 & 晚唐 & $\begin{array}{l}\text { 《2000中國重要考 } \\
\text { 古發現》 }\end{array}$ \\
\hline 12 & $\begin{array}{l}\text { 陕西臨潼唐代慶 } \\
\text { 山寺塔基地宮 }\end{array}$ & 1985 & 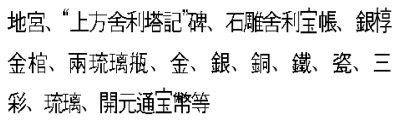 & 唐開元29年 & 〈文博) 85.5 \\
\hline 13 & $\begin{array}{l}\text { 陕西扶風法門寺 } \\
\text { 塔基地宮 }\end{array}$ & 1987 & $\begin{array}{l}\text { 放第一枚佛指的八重宝函；置第二枚佛指的漢 } \\
\text { 白玉灵帳三重函棺；盛第三枚佛指的五重函 } \\
\text { 棺：藏第四枚佛指的漢白玉阿育三塔三重塔 } \\
\text { 棺。供養品有金銀器、秘色瓷、琉璃器、石 } \\
\text { 雕、絲織品等 }\end{array}$ & $\begin{array}{c}\text { 唐咸通15年(8 } \\
74 \text { 年) }\end{array}$ & \begin{tabular}{|} 
佉門寺考古發掘 \\
報告 ，文物出版社 0 \\
7 年
\end{tabular} \\
\hline 14 & $\begin{array}{l}\text { 山東惠民出土唐 } \\
\text { 末五代定光佛舍 } \\
\quad \text { 利棺 }\end{array}$ & 1972 & $\begin{array}{l}\text { 定光佛(祭灯佛)舍利棺，石楟、鐵棺、數枚“開 } \\
\text { 元通宝”錢 }\end{array}$ & 唐末 & (文物) 87.3 \\
\hline 15 & $\begin{array}{l}\text { 甘肅灵台五代舍 } \\
\text { 利地宮 }\end{array}$ & 1957 & 石棺、漆盒、琉缡狐、墓志 鈳镜 & 五代 & (文物) 83.2 \\
\hline 16 & $\begin{array}{l}\text { 浙江杭州雷峰塔 } \\
\text { 基地宮 }\end{array}$ & $\begin{array}{c}2000-20 \\
01\end{array}$ & 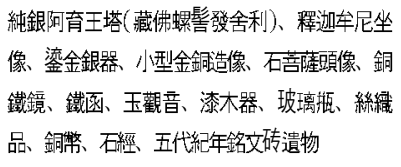 & 五代 & $\begin{array}{c}\text { (2001 } \\
\text { 中國重要考古發現) }\end{array}$ \\
\hline 17 & $\begin{array}{l}\text { 江蘇萪州虎自北 } \\
\text { 宋云岩寺塔 }\end{array}$ & 1957 & 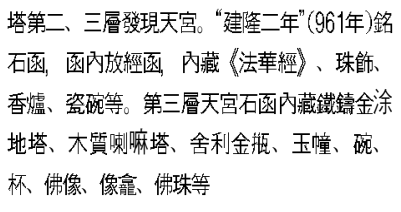 & 北宋 & $\begin{array}{l}\text { 穌州虎丘塔出士 } \\
\text { 文物》, } \\
\text { 文物出版58年 }\end{array}$ \\
\hline 18 & $\begin{array}{c}\text { 河北定縣兩座宋 } \\
\text { 代塔基 }\end{array}$ & 1969 & 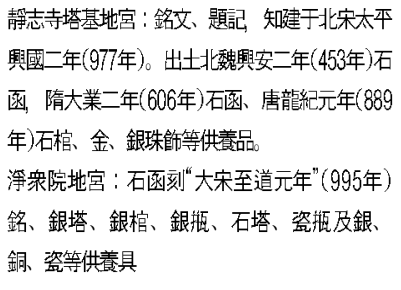 & 北宋 & (文物) 72.8 \\
\hline 19 & $\begin{array}{l}\text { 河南密縣原法海 } \\
\text { 寺旧址上, 墢現 }\end{array}$ & 1966 & 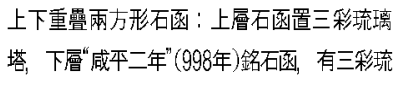 & 北宋 & $\langle$ 文物 $\rangle 72.8$ \\
\hline
\end{tabular}




\begin{tabular}{|c|c|c|c|c|c|}
\hline 序号 & 發現地点 & 發現時間 & 出土主要遺迹 遺物 & 年代 & 備注 \\
\hline & 了北宋塔基地宮 & & $\begin{array}{l}\text { 璃方塔、三棌琉璃舍利函、瓷舍利嗢、銀舍利 } \\
\text { 盒、琉璃器、銅佛像、䤧錢 }\end{array}$ & & \\
\hline 20 & $\begin{array}{l}\text { 江蘇蘇州案瑞光 } \\
\text { 寺舍利寺塔 }\end{array}$ & 1978 & 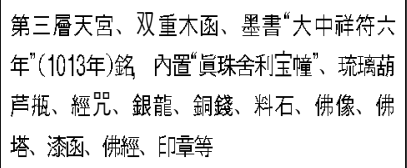 & 北宋 & $\begin{array}{l}\text { (文物) } 79.11 \text { : } \\
86.9\end{array}$ \\
\hline 21 & $\begin{array}{l}\text { 江蘇連云港海清 } \\
\text { 寺北宋阿育王塔 }\end{array}$ & & 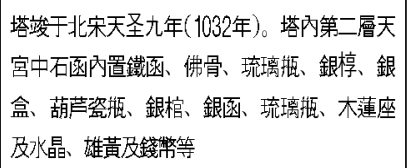 & 北宋 & (文物) 81.7 \\
\hline 22 & $\begin{array}{l}\text { 浙江瑞安北宋慧 } \\
\text { 光塔 }\end{array}$ & 1966 & 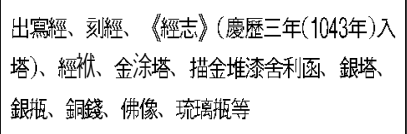 & 北宋 & 《文物》 73.1 \\
\hline 23 & $\begin{array}{l}\text { 浙江金華北宋万 } \\
\text { 佛塔塔基 }\end{array}$ & 1956 & $\begin{array}{l}\text { 刻“嘉佑七年”(1062年)鉻經傽。幛前放鐵函、佛 } \\
\text { 像、塔、盒 鏡、錢幣 }\end{array}$ & 北宋 & $\begin{array}{c}\text { 《金華万佛塔出土 } \\
\text { 文物》， } \\
\text { 文物出版社 } 58 \text { 年 }\end{array}$ \\
\hline 24 & $\begin{array}{c}\text { 上海松江北宋興 } \\
\text { 敎寺塔地宮 }\end{array}$ & 1974 & $\begin{array}{l}\text { 北宋熙宁、元佑年間(1068-1093年)所建。出 } \\
\text { 土石函、唐宋銅錢、銅坐佛、漆函、銅卧佛和 } \\
\text { 大小銀函、銀珠、沉香 佛牙、舍利子等 }\end{array}$ & 北宋 & (考古) 83.12 \\
\hline 25 & $\begin{array}{l}\text { 江䱶鋇江甘露寺 } \\
\text { 㷊代鐵塔地宮 }\end{array}$ & 1960 & 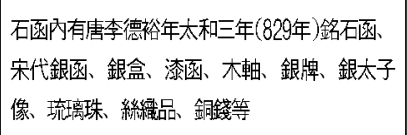 & 唐宋 & (考古) 61.6 \\
\hline 26 & $\begin{array}{c}\text { 山東濟宁北宋鐵 } \\
\text { 塔 }\end{array}$ & 1973 & $\begin{array}{l}\text { 出北宋崇宁四年 }(1105 \text { 年)鐵塔。第一層天宮中 } \\
\text { 置舍利石函、瓷函和木椂及銅佛、銅鏡、鐵 } \\
\text { 牌、併經 石碑 }\end{array}$ & 北宋 & (文物) 87.2 \\
\hline 27 & $\begin{array}{c}\text { 云南大理崇圣寺 } \\
\text { 千尋塔 }\end{array}$ & 1979 & 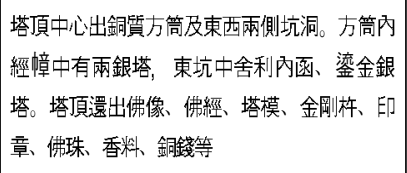 & $\begin{array}{c}\text { 大理國時期 } \\
(1000 \sim 1160 \text { 年 })\end{array}$ & 《考古學埌〉 81.2 \\
\hline 28 & $\begin{array}{l}\text { 浙江麗水碧湖鋇 } \\
\text { 南宋塔基地宮 }\end{array}$ & 1960 & $\begin{array}{l}\text { 出有佛經、銅佛、銅鏡、砖刻、碑刻、琉璃 } \\
\text { 珠、錢幣、瓷残器及佛牙等 }\end{array}$ & 南宋 & 《文物) 63.3 \\
\hline 29 & $\begin{array}{c}\text { 北京順義縣潦淨 } \\
\text { 光舍利塔基 }\end{array}$ & 1963 & 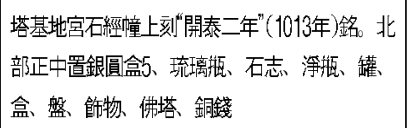 & 遼 & (文物) 64.8 \\
\hline
\end{tabular}




\begin{tabular}{|c|c|c|c|c|c|}
\hline 序号 & 發現地点 & 發現時間 & 出土主要遺迹 遺物 & 年代 & 備注 \\
\hline 30 & $\begin{array}{l}\text { 吉林農安万金墽? } \\
\text { 遼代塔基 }\end{array}$ & 1970 & 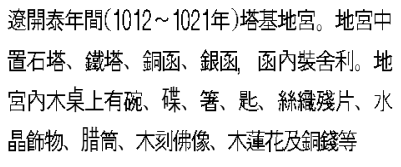 & 遼 & (文物) 73.8 \\
\hline 31 & $\begin{array}{l}\text { 內蒙古宁城武官 } \\
\text { 營子遼塔地宮 }\end{array}$ & 1954 & 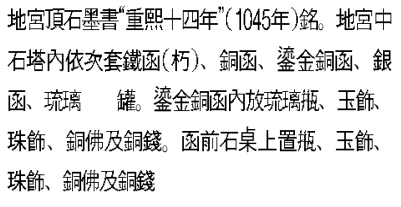 & 遼 & 《考古〉 64.11 \\
\hline 32 & $\begin{array}{c}\text { 北京房山北鄭柎 } \\
\text { 䢒塔基地宮 }\end{array}$ & 1977 & $\begin{array}{l}\text { 地宮中石函刻“重熙二十年”( } 1051 \text { 年)銘。函內放 } \\
\text { 石佛像、瓷碟、銅碗、赽、鏡、銀碗、碟、 } \\
\text { 筇、佛喓、幡架、宝花和水晶珠及舍利。在地 } \\
\text { 宮石板盖上立石憧 }\end{array}$ & 遼 & (考古) 80.2 \\
\hline 33 & $\begin{array}{c}\text { 遼丁宁朝陽遼代北 } \\
\text { 塔 }\end{array}$ & 1986 & 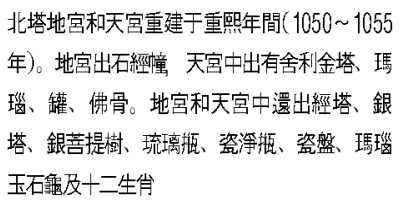 & 遼 & 《文物》 92.7 \\
\hline 34 & $\begin{array}{c}\text { 天津蓟縣稀樂寺 } \\
\text { 遼塔天宮 }\end{array}$ & 1983 & 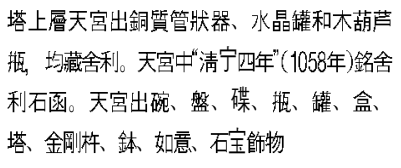 & 遼 & 《考古學埌〉 89.1 \\
\hline 35 & $\begin{array}{c}\text { 遼丁宁沈陽潦崇壽 } \\
\text { 寺向塔 }\end{array}$ & 1956 & 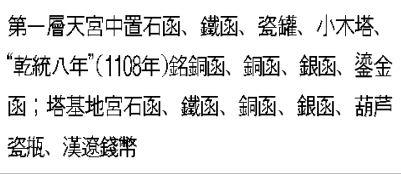 & 遵 & $\begin{array}{c}\text { 《文物參考資料》57 } \\
\text {.8: } \\
\text { 《考古通訊》 } 57.6\end{array}$ \\
\hline 36 & $\begin{array}{c}\text { 河北易縣遼深覺 } \\
\text { 寺舍利地宮 }\end{array}$ & 1977 & 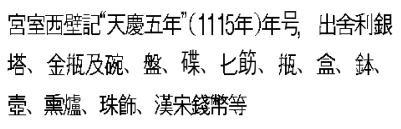 & 遼 & (文物) 86.9 \\
\hline 37 & $\begin{array}{c}\text { 山西應縣賞佛宮 } \\
\text { 寺木塔 }\end{array}$ & 1974 & $\begin{array}{l}\text { 塔第二、四層主像凹槽內均墢現銀盒，內盛七 } \\
\text { 宝与佛牙。第四層主佛凹槽內放大量經尊 }\end{array}$ & 遼末金初 & (文物) 82.6 \\
\hline 38 & $\begin{array}{l}\text { 浙江崇德崇福寺 } \\
\text { 西塔塔頂 }\end{array}$ & 1955 & $\begin{array}{l}\text { 明代安放吳越金涂塔，塔內銀盒里藏舍利及 } \\
\text { 金、銀、玉五飾物、銅錢： } \\
\text { 明正德九年 }(1515 \text { 年)入藏有錾花銀盒、七香 }\end{array}$ & 明、淸 & $\begin{array}{c}\text { 《文物參考資料》 } \\
56.1\end{array}$ \\
\hline
\end{tabular}




\begin{tabular}{|c|c|c|c|c|c|}
\hline 序号 & 發現地点 & 發現時間 & 出土主要遺迹 遺物 & 年代 & 備注 \\
\hline & & & 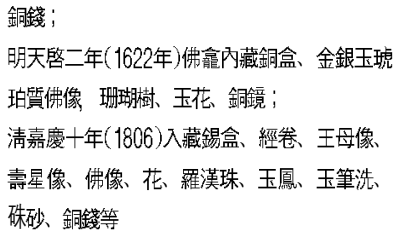 & & \\
\hline 39 & $\begin{array}{l}\text { 山東杨城鐵塔塔 } \\
\text { 基地宮中明代舍 } \\
\text { 利器具 }\end{array}$ & 1973 & $\begin{array}{l}\text { 鐵塔北宋晚期建，其地宮內墢現明代重㓐的石 } \\
\text { 函、銀函及錢幣 }\end{array}$ & 明代 & 〈考古〉 87.2 \\
\hline 40 & $\begin{array}{l}\text { 江蘇南京秦淮嵒 } \\
\text { 中華門外、雨花 } \\
\text { 路束䀧報思寺塔 } \\
\text { 基地宮 }\end{array}$ & $\begin{array}{l}2007^{-} \\
2010\end{array}$ & $\begin{array}{l}\text { 北宋大中祄符 } 4 \text { 年 (1101年)所建、明代重建時沿 } \\
\text { 用的塔基地宮中，出土了鐵函、石函、銀楟 } \\
\text { 等。鐵函中七宝阿育王塔 內藏“佛頂貪骨” }\end{array}$ & $\begin{array}{c}\text { 明代永樂至宣 } \\
\text { 德年間 }\end{array}$ & $\begin{array}{c}\langle 008 \\
\text { 中國重要考古發現》 } \\
\text { (2010 } \\
\text { 中國重要考古墢現》 }\end{array}$ \\
\hline
\end{tabular}

上表中，陕西法门寺、浙江杭州雷峰塔、江苏南京大报恩寺塔基地宫出土 的舍利器具, 都是分别是唐代、五代、明代皇家供奉的舍利及其器具, 等级 高，工艺精，其考古发现引起的社会反响最强烈。除上述表列内容以外，其 他还有一些塔基地宫被发掘，在此不一一列举了。

(2)、佛像窝藏或佛像组群的发现

几十年来, 河北蚛城、曲阳、河南洛阳、陕西西安等各地持续不断地有佛 像窝藏或佛像组群发现, 数量众多, 此不一一列举, 此谨以出土石、铜、泥 佛像较多的西安市为例进行说明 ${ }^{4)}$ 。

\begin{tabular}{|c|c|c|c|c|c|}
\hline 序号 & 出土地点 & $\begin{array}{l}\text { 出土 } \\
\text { 時間 }\end{array}$ & 佛像种類數量 & 時代 & 備注 \\
\hline 1 & 蓮湖區大土門村南 & 1957年 & $\begin{array}{l}\text { 泥塑像、石像數百尊，部分造像刻有 } \\
\text { "大唐善業尼" }\end{array}$ & 唐 & 金城坊開善尼寺遺址 \\
\hline 2 & 西安東郊新城區電厂路龍華村北側 & 1959年 & 石像害藏佛像10 & 唐 & 長樂坊大安國寺 \\
\hline
\end{tabular}




\begin{tabular}{|c|c|c|c|c|c|}
\hline 序号 & 出土地点 & $\begin{array}{l}\text { 出土 } \\
\text { 時間 }\end{array}$ & 佛候种類數量 & 時代 & 備注 \\
\hline 3 & 未央區漢城街道辦事處范家堡 & 1971 & 佛和菩薩像 & 北周 & \\
\hline 4 & 未央區六村堡街道辦事處東席村 & 1973 & 菩隡像1、四面造像碑1 & 北周 & \\
\hline 5 & 雁塔埕小寨街道東八里村 & 1974年 & 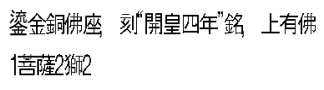 & 隋 & 昌樂坊 \\
\hline 6 & 未央區草灘街道辦事處李家街村 & 1975 & 佛含像17 & 北周 & \\
\hline 7 & 未央區六村堡街道辦事中官亭村 & 1982 & 立佛像2、觀晋立像(保定5年題記)1 & 北周 & \\
\hline 8 & 涟鎬西路以南、勞動南路以西 & $\begin{array}{r}1982 \\
1986\end{array}$ & 石造像窝藏，附近出百件善業泥像 & 唐 & 礼泉寺 \\
\hline 9 & 未央區未央宮乵神考處大劉寨村西 & 1984 & 佛頭像 & 北围 & \\
\hline 10 & 蓮湖區空軍通訊學院 & & 立佛像 & 北周 & \\
\hline 11 & 蓮湖豆西稅师西北空軍通訊學院 & 1984等 & $\begin{array}{l}\text { 出北朝、隋唐石像窗藏，出佛、菩薩 } \\
\text { 石像32 }\end{array}$ & & $\begin{array}{c}\text { 金城坊樂善尼寺(溫 } \\
\text { 國寺) }\end{array}$ \\
\hline 12 & 西安大南門外冊家村南 & 1985 & 窝藏坑石佛造像11 & 隋 & 崇義㘦正覺寺 \\
\hline 13 & $\begin{array}{l}\text { 蓮湖區桃園街道辦事處原西安民航 } \\
\text { 机場 }\end{array}$ & 1986 & 觀晋像1、釋砶千佛造像碑1、佛頭 & 北周 & \\
\hline 14 & 未央區漢城街道辦事處西查村 & 1992 & 觀晋像了 & 北周 & \\
\hline 15 & 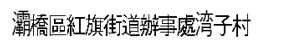 & 2004 & 立佛像的、佛座4 & 北围 & \\
\hline 16 & $\begin{array}{l}\text { 西安未央區中查村西北北周長安城 } \\
\text { 宮城之南 }\end{array}$ & 2004 & $\begin{array}{l}\text { 造像31件，包括立像、坐像、立菩薩 } \\
\text { 像等 }\end{array}$ & 北周 & $\begin{array}{c}\langle\text { 〈古都遺珍一長安 } \\
\text { 城出土的北周佛郄造 } \\
\text { 像〉，文物出版社 } 20 \\
10 \text { 年 }\end{array}$ \\
\hline 17 & 未央區六村堡街道辦事處䁿寨村 & 2007 & $\begin{array}{l}\text { 佛像、佛頍像2、菩薩像了、菩薩頭像 } \\
\text { 、殘佛坐 } 2\end{array}$ & 北周 & \\
\hline
\end{tabular}

(3)、佛寺遗址

除了上面佛塔地宫及佛像组群的考古发现之外，佛寺遗址的考古调查和发 掘工作正越来越受到重视，近年来新发现逐步增多起来。 
1963、1979 1981年，中国科学院考古研究所调查和发掘了河南省洛阳市 东汉魏洛阳故城的永宁寺遗址。经勘察，寺院平面呈长方形，南北305米东 西260米。塔基位于围墙内正中部位，平面呈方形，台基四边用青石垒砌压 边, 基座四面均设踏道。塔以北有一片较大的夯土台基遗迹, 应为正殿基 址。考古揭示其为布局的中国早期佛寺建筑前塔后殿的典型布局实例。寺址出 土大量石雕瓦瓦当、佛教泥塑残像。佛教泥塑残像有大小两种, 大像较少, 有佛和菩萨造像。小像出土约300馀件, 多为贴壁“影塑”, 包括飞天.菩萨.比 丘以及世俗供养人像，有高冠大履毫衣博带的上层人物及其侍从:文吏和武士 等造型精致, 形态生动 ${ }^{5)}$ 。

1981年，山西省大同市博物馆对大同市东北方山南麓的北魏思远佛寺遗址 进行了考古发掘,揭露了北魏、辽金和明清等时代的文化层，清理了北魏时期 的山门、实心体回廊式塔基、佛殿、僧房等建筑遗迹, 出土北魏莲花化生瓦 当、佛教造像残件等

2010年, 山西云冈石窟研究院发现了一组较完整的北魏寺庙遗址, 具体有 北廊房、东廊房、西廊房、南廊房、塔基和砖瓦窑遗址。2011年, 又在距此 寺院400米的窟顶发现了一处体量更大的北魏石结构塔基遗址。佛塔建筑的 结构，它由三部分构成，即地基(基础)、基座、石塔底层建筑基座平面接近 正方形，坐北朝南，基座四面周围石砌墙体，基座南面设东西向的东斜坡踏 道和西斜坡踏道各一条，可以从东、西侧两个不同方向登临上塔的基座。底 层建筑由塔芯实体、环绕塔芯的回廊两部分建筑组成。塔身正中有贯穿上下 的石塔轴心柱刹柱。这些考古发掘为北魏畉道元《水经注》中对云冈石窟“山 堂水殿、烟寺相望”的描写提供了实证。

1996年10月, 山东青州发现龙兴寺佛像窝藏，窝藏东西长8. 6米, 南北 宽6. 7 米, 深度不到3米, 出土佛像 400 余尊, 年代大多是南北朝时期”。

2002年，河北临漳县赵彭城㸃城遗址发掘出北朝佛寺塔基遗迹，其后在佛 塔周边持续进行了考古工作。2011 2012年度发掘了中轴线北端大型建筑基 
址、东南院大型建筑基址，取得了对该寺院遗址布局认识的重要突破，证明 赵彭城北朝佛寺是以佛塔为中心、重要轴线上建造大型殿堂式建筑、多院落式 布局的大型佛寺。2012年1月，又在斨南城东郭城区、北吴庄村北抢救性发掘 了一处大型佛教造像埋藏坑。出土造像数量达到2895件(块), 多数造像保存 有较好的彩绘和贴金痕迹, 时代跨越北魏、东魏、北齐、北周、隋和唐代, 可谓建国以来迄今所知出土数量最多的佛教造像埋藏坑

1997年至2000年, 洛阳市文物管理局、龙门石窟研究所与意大利中远东研 究所、那波利大学东方文化研究所合作, 对洛阳龙门石窟以西的唐奉先寺 遗址进行了发掘，发现殿址、水道等遗迹以及瓷器、石刻造像等遗物”。

2005年至2006年间，对四川省成都市工怽来县的唐宋时期的龙兴寺遗址进行 了考古调查和发掘，发现房址、方形砖塔基址、北宋罗汉殿址、水井、佛像 坑、墓葬等遗迹, 出土石刻造像、经幢、“大中九年”(855年)天王石像、石刻 经版、琉璃构件、陶瓷器、铜镜、钱币等大量遗物 ${ }^{10}$ 。

1973年和1980年, 中国科学院考古研究所发掘了西安市铁炉庙村的唐密教 祖庭青龙寺遗址，发掘出东西并列的两组院落以及寺院北大门遗迹。其中, 西院为带有回廊的塔院，有中三门、木塔，塔北佛殿及四面回廊等基址，东 院清理出早晚两期叠压的殿堂基址，柱网坑排列整齐 ${ }^{11)}$ 。

1985、1992年，中国科学院考古研究所在西安市碑林区白庙村发掘了唐长 安城名寺的西明寺遗址, 两次发掘近万平方米。揭露出寺院东部的饿一组三 个院落组成的偏院遗址，清理出前院前殿、中殿、北殿、四面回廊院墙、庭 院、水道滲井、道路、南部中央夹道等遗迹, 出土石灯、流金铜佛像、石佛 像、陶佛像、碑刻残块、石茶碾、瓷碗、瓷桂子、陶砚、玻璃鱼饰及“乾元 重宝”、“开元通宝”钱币等遗物 ${ }^{12}$ 。

2011年开始, 内蒙古文物考古研究所、中国社会科学院考古研究所内蒙古 二队组成了辽上京城联合考古队，对内蒙赤峰市巴林左旗林东镇东南的辽代 上京皇城西山坡佛寺遗址进行了全面考古发掘，揭露出佛寺的长方形院落、四 
周院墙、中轴线上大型六角形砖木混合结构佛殿、左右两侧对称布置的小型 六角形砖塔、大殿前小型建筑基址和广场等遗迹，出土贴金泥塑人面像、石 像、石经幢、铜镜、铁器、陶瓷器等大量遗物, 为研究辽代考古、历史、 佛教和建筑等提供了十分重要的实物资料 ${ }^{13)}$ 。

\section{2、邊疆地區}

1957年, 考古学家黄文弱第四次进入新疆, 调查了古城、寺庙等遗址, 后 经考古所整理，1983出版有《新疆考古发掘报告》。

1963、1964年中国科学院考古研究所等对黑龙江宁安市渤海镇境内渤海国 上京龙泉府遗址进行了调查和发掘，确定1-9号佛寺9处。其中，东城西起第 一列、北数第二坊西部的 1 号佛寺规模较大, 由主殿、穿廊和东西二室三部分 组成，呈凸字形殿阁并存形，三者台基连为一体。主殿，东西23.68米、南 北20米。而城北外的9号佛寺为长方形独立佛殿, 面阔5间, 进深 4 间, 外有 回廊, 殿内中心坛座减杜 ${ }^{14)}$ 。

1959年和1986年, 宿白先生两次入西藏拉萨、山南、日喀则、江孜等地 区，进行调查，不辞辛劳，亲自记录、绘图，并运用考古类型学原理，对 西藏佛寺的平面布局以及科学分期进行了研究, 先后撰成了《西藏拉萨地区 佛寺调查记》、《西藏山南地区佛寺调查记》、《西藏日喀则地区寺庙调 查记》等系列研究论文, 1996年结集为《藏传佛教寺院考古》一书, 奠定了 西藏佛教考古研究的基础。

1985年国家文物局组织了对西藏阿里地区的文物普查，主要对象集中在以 古格王国时期都城札不让为中心的古格时期建筑遗址, 其调查成果体现于 1991年出版的《古格故城》(上、下册)中。

2005年至2007年, 陕西省考古研究所和西藏文物保护研究所合作, 对西藏 萨迦寺的北寺遗址进行了全面考古调查和局部发掘，发掘清理了萨迦南寺羊 
马城城墙及护城河遗迹、北寺的得确颇章遗址、乌孜大殿遗址以及塔林的部 分塔基进行了, 同时还对萨迦北寺的其他建筑遗迹如桑阿德吉林、东热布拉 康等进行了实地考古调查和局部清理 ${ }^{15)}$ 。

新疆楼兰、尼雅、交河故城等丝绸之路沿线的大遗址中都发现有佛教建筑 遗址遗迹，都是“木骨泥墙法”构筑，包括佛塔、寺院、佛堂和佛坛四种形式。

1995年, 由新疆文物考古研究所与日本有爸机构合作组成的中日尼雅遗址 学术考察队对新疆民丰县沙漠腹地魏晋时期尼雅佛教寺院遗址。寺院南有佛 殿(FS)，西是僧房和讲经堂(FD)，北有带前廊的房址，中央为一面积约500平 方米的广场，可见是由佛殿、僧房和讲经堂等五组单元建筑构成的一座完整 佛教寺院，出土木雕天人像、佛和菩萨像的一些壁画残片 ${ }^{16)}$ 。

1993年, 新疆文物考古研究所与法国科研中心135所合作在和田县城北约 220 多公里的沙漠中发现并发掘了喀拉墩附近魏晋时期的两座佛殿遗址(N61、 N62)。墙壁都用“木骨泥墙法”构筑，整体平面均呈“回”字形，内为正方形佛 座台基，四周是行道，内外两层墙壁间相距约为 2 米。出土立佛和坐佛的一些 壁画残片 ${ }^{17)}$ 。

2002年10月,新疆文物局、新疆文物考古研究所和日本佛教大学尼雅遗迹学 术研究机构共同组队，在策勒县城北约 90 公里的沙漠中，发现并发掘了一座 佛寺遗址(CD4)，平面呈长方形，南北长8.2米、东西宽6.02米，墙壁也用“木 骨泥墙法”构筑，出土有佛像、骑士等形象的壁画残片和墨迹，婆罗谜文题迹 等。该寺形制与克里雅河喀拉墩附近的佛寺相同，其始筑年代早到公元5世 纪, 使用至8世纪吐蕃占领于蒖前 ${ }^{18)}$ 。

2002年至2006, 中国社会科学院考古研究所在新疆策勒县达玛沟乡东南 约7公里的沙丘中发掘了托普鲁克墩佛寺遗址。其中, 1 号遗址为小型佛堂遗 址，坐北朝南，建筑平面呈长方形，南北长 2 米、东西宽1.7米。屋内紧贴北 墙的覆莲台上为主尊泥塑佛像，残高1.45米，其四面残壁保留大量立佛、坐 佛、菩萨等壁画。2 号遗址坐西朝东, 为一“回”字形的佛堂, 内置土坏至砌 
的方形泥塑佛像台基。佛堂东部和北部各加一个长方形的侧堂, 出土佛头和 千佛壁画残块、毗卢遮那佛木板画、柱刹、擦擦、五铢和开元通宝铜钱等。 其始建年代有可能是开元年间(713-741年)。2006年，还对达玛沟喀拉墩1号 佛教遗址进行了小范围的发掘，出土佛头、千手千眼观音、菩萨头像、小坐 佛等壁画残块。3.举团扇背光部分壁画残块。4.壁画残块。5.壁画残块6.卷 草纹壁画残块等，其始建时代为公元7世纪 ${ }^{19}$ 。

1979年，中国社会科学院考古研究所发掘了新疆吉木萨尔县北庭古城之西 的高昌回鹘佛寺遗址，清理了寺院的南面和东面，揭示出寺院平面布局和结 构佛寺平面呈长方形，地面为夯土台基，地面以上全部用土坏砌筑。整个遗 址可分为南、北两大部分:南面是残庭院、配殿、僧房、库房等建筑群，北部 是残高约14.3米的正殿，其四周环筑洞窟。殿外南面上部有一层洞晟，东、 北和西三面外墙都设两层佛洞宒。殿内设佛坛供佛、菩萨、天王和罗汉像, 还有一尊涅磐佛大像。塑像当年多贴金妆彩。回鹘文题记中“神圣的亦都护” 和“长史”“公主”之名，证明7寺院的规格之高及与王室的爸系。佛寺遗址的使 用年代约在公元10世纪中期至13世纪中期 ${ }^{20)}$ 。

二、

中国佛教源远流长，遗址遗物异常丰富，无论是建筑单元，还是造像、 壁画、文书佛经等等，都是研究的对象，凡此都决定了中国佛教考古学研究 内容之广、研究难度之巨。几十年来, 中国佛教考古学领域发表的有爸论 文汗牛充栋，涉及到诸领域的各个方面，故此，我们不可能在短短的一篇文 章中尽掠其美，而只能作一管窥之举。 


\section{(一) 石窟寺考古方法的改進}

在石窟寺的考古调查研究方法中, 过去常规的方法时是用类型学的方法, 进行对比、分类、组合的研究。但从上世纪八十年代起, 以宿白先生为首, 开始对以前的方法进行反思和革新提高。一是将考古地层学的方法应用在石 窟寺的调查研究中, 即借用了考古地层学中早晚文化层的叠压打破爷采, 来 分析归纳石窟中早晚佛匬、雕像、纹饰、甚至彩绘等之间的叠压打破爷系， 从而得出其年代早晚的可靠结论，但其叠压打破爸系与早晚文化层爸系是相 反的 : 即晚期洞窟中决不会有早期雕丵的造像, 但可能会有早期遗风 ; 在早 期洞窟中, 则可能会有晚期补刻的造像。这一原理在云冈等石窟研究中都得 到了运用 ${ }^{211}$ 。二是认识到考古发掘对于石窟寺研究至䏌重要。如通过对地层 的发掘，发现了云冈石窟历史上北魏、唐、辽金时期的窟信建筑遗迹，在龙 门擂鼓台窟前区域，发现了唐代窟前踏道、窟前殿堂包石台基、宋代造像题 记及唐宋时期窟前道路等。这些成果对于深入了解石窟寺的建筑沿革、分期 断代等都具有重要的意义。

\section{(二)、關于塔基地宮和舍利㓐埋方式的研究}

历年来, 中国发掘清理的佛寺塔基数量众多，主要有河北定县北魏太和五 年塔基、河南洛阳北魏故城永宁寺塔址、河北临漳县东魏北齐佛寺塔址、河 北定县隋静志寺塔基、陕西耀县隋神德寺舍利塔基、陕西周至仙游寺法王 塔、陕西西安隋唐青龙寺塔址、陕西扶风唐法门寺塔址、陕西临潼唐庆山寺 塔基、甘肃云泾大云寺塔基、山西太原市太山唐龙泉寺塔基等，从而引起了 学者们的注意和研究。其中, 徐苹芳先生的研究最为权威。他在《新中国的 考古发现和研究》、《中国大百科全书・考古学》的有爸章节条目及《中 
国舍利塔基考述》一文中，曾广泛收集1982年以前有爸中国舍利塔基的考古 资料，并作了系统的分析研究，总结出中国舍利塔基及其舍利痓埋器具的发 展演变规律，提出了这样的论点 : 即佛塔从中心塔刹为中心的木塔向以楼图 式或密檐式砖塔为主的塔形转变过程中, 也发生了从使用砖石函和玻璃瓶到 使用地宫和金棺银楟进行舍利痓埋的方式的变化过程 ${ }^{22}$ 。当然，其他学者也 作过相爸的研究, 丰富和补充了徐苹芳先生的观点 ${ }^{23}$ 。特别是最近二十几年 的佛塔塔基的新发现，也引证了其结论之实。

\section{(三)、佛寺形制布局的研究}

中国发掘的佛寺遗址数量屈指可数，主要有：山西大同北魏方山思远浮图 遗址、河南洛阳北魏故城永宁寺遗址、河北临漳县班城东魏北齐佛寺遗址、 陕西西安隋唐青龙寺遗址、陕西西安唐西明寺遗址、河南洛阳唐奉先寺遗址 等。这些遗址除平城思远浮图遗址外，都是局部发掘，且主要在各都城遗址 内或附近。

1997年，宿白先生根据考古资料，先后发表了 《东汉魏晋南北朝佛寺布局 初探》、《隋代佛寺布局》两篇论文, 对隋代及以前的佛寺布局进行了全面 的研究。他认为: 公元 5 世纪北魏迁洛之前, 佛寺以塔为中心, 但开始出现 讲堂、禅房。公元 5 世纪至南北朝结束，一般佛寺仍以塔为中心，塔居殿前。 而皇家寺院则开始出现别院山池等。隋代佛寺仍沿前期以佛塔为主要建置的 传统布局 ${ }^{24)}$ 。

唐代佛寺非常发达，佛寺布局，研究者根据遗址发掘资料，结合敦煌壁 画、文献记载等材料, 提出了唐朝时佛寺布局已转变成佛殿为主、塔居次要 地位、多院落的形式。唐朝时佛寺形制布局已转变为塔佛殿为主、塔居次要 地位、多院落的形式 ${ }^{25)}$ 。 
至于唐代以后的佛寺，因禅宗的兴盛，禅寺已占绝大多数，其布局有了新 的变化，伽蓝七堂格局成为主流 ${ }^{26}$ 。

\section{(四)、有關長江流域器物上佛敉圖像及佛㪍南傳之路的考察与研究}

1991年起, 由中国南京艺术学院、北京大学、南京博物院和日本龙谷大学 联合组成的“佛教初传南方之路”课题研究组先后五次沿长江流域对四川、湖 南、湖北、江苏、广东等十个省、市、地区“早期佛教造像的南传系统”展开 了实地考察和调查。两年后, 在此次调查的基础上, 由上述单位共同编著, 中国文物出版社和日本龙谷大学联合出版了文物图录《佛教初传南方之 路》, 该图录集中了牛个世纪以来发现的有佛像造型的相爸的考古遗存, 这 批文物的佛像造型大多雕饰或刻画于其它的承载体上（佛像造型艺术品：崖 墓浮雕中的石刻佛像、摇钱树插座、铜钱树、东汉末至魏晋的画像石墓、洌金 金铜饰件、铜镜、陶瓷谷仓罐即魂瓶、青瓷器具，长江上游四川地区所见 钱树及崖墓石刻上的佛像形象, 在长江中游出土的文物中仅见于铜质器物如 铜镜，而堆塑于魂瓶上的佛形象也只有在长江下游的江浙一带可以受见它的 身影。表现在佛像承载体上的这种差异是地区性的，)因而与后来完全佛教 意义上的独立的佛教造像不同，只能说是一些有佛教含义的形象而已，称其 为佛的形像或更妥当。这类造型仅见于南方，绝大部分发现于长江流域，时 期则以 2-4世纪为限, 同一时期北方同类艺术品很少被发现，于是，这类佛 像艺术品与佛教初传中国的兊系, 南方和北方，海路与陆路在早期佛教传入 中国过程中的地位和作用等问题，相因而至。佛教初传时期，南方和西域通 过不同的途径，依靠各自的传播方式，形成最初的佛传根据地，并继而将佛 的信息传递到中原，从这个意义上讲，佛教向中国传播的方式和途径是多元 的，陆路和海路在早期佛教传入中国的过程中，其地位和作用是同等的，似 不必分出孰先孰后 ${ }^{27)}$ 。 


\section{（五）關于石窟、佛造像樣式与風格的研究}

爸于石窟样式和风格的继承和流变, 宿白先生曾发表过 《京州石窟遗迹与“凉 州模式》、《平城实力的集聚和“云冈模式”的形成与发展》两文。在前文中, 宿白先生根据自己1994年对天梯山石窟的实地考察资料，确定中国石窟起源于天 梯山石窟的第一、第四窟，即早期北凉洞窟，或凉州石窟遗迹。北凉沮渠蒙逊 开對的天梯山石窟就是“凉州石窟”，创立了“凉州模式”(十六国时期，凉州为佛 教文化中心)。云冈石窟 21 个主要洞窟，包括县曜五窟，具有凉州及龟兹佛教之 遗风。而仿照云冈石窟开羳的龙门石窟，也没有脱出凉州石窟的模式。在后文 中，宿白先生指出云冈石窟实现了印度、中亚等多种佛教艺术造像风格的融会 贯通，开始了“中国化”，其中期石窟中出现的中国宫殿建筑式样雕刻、中国式 佛像愈、中国式建筑装饰等，形成了中国佛教艺术发展的转折点的“云冈模 式”。敦煌莫高窟、龙门石窟中的北魏时期造像均受到云冈石窟的影响 8 。

至于佛像风格，宿白先生在1999年撰写了《青州城考略- - 青州城与龙兴 寺之一》、《龙兴寺沿革- - 青州城与龙兴寺之二》和《青州龙兴寺窑藏 所出佛像的几个问题 - - 青州城与龙兴寺之三》)。三篇文章, 敏锐地指出 龙兴寺造像风格在东魏末期与北齐之际发生了突变, “一种有别于亭衣博带 式服饰的佛教造像逐渐兴起”，即薄衣透体的佛像体现出青州风格的另一个 方面。此种风格佛像，肉髧微凸，双目低垂，体态修长、健美，肩宽而平， 胸部微微隆起, 小腹略突, 细腰, 服饰轻薄, 紧贴身体, 很好地再现了“曹 衣出水”的效果。菩萨像也是如此。这种“青州风格”主要流行于北齐时期量”。

金维诺先生认为“曹家样” 源於中亚粟特, 衣薄而透明, 如“出水”一样的风 格。河北曲阳修德寺、山东青州龙兴寺出土的北朝早期造像, 属于比较典型的 秀骨清像式，或称“青州样式”或“薄衣式佛像”，表面平滑、线刻简单，目光

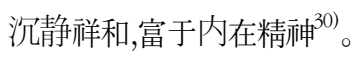

上述佛像样式和风格的确立, 为此方面的研究提供了准绳。 


\section{(六)、陵墓佛寺遺址的探討}

陵寺的讨论是一个新的课题。最早注意并论述陵寺者为白文固, 他在《宋 代的功德寺和坟寺》一文指出：“陵寺，就是皇帝的陵旁寺。”北宋时期，帝陵 附近，都修有陵寺，已经形成制度。而溯其源头，可追至魏晋南北朝时期 ${ }^{31}$ 。

其后，舟万里对中国古代的陵寺制度进行了系统的梳理，对唐代的陵寺做 了相应的考证，提出了 “中国古代帝陵建寺制度，滥解于南北朝，发展于隋唐， 成熟于北宋”的观点。北魏永固陵前的思远佛寺即为早期的陵寺。所谓陵寺, 特指修建于皇帝陵园附近的寺院，是帝陵附属建筑的一部分。一般来说，其修 建者多为后代皇帝或皇室成员，出于一定的目的或传统习惯而为前代皇帝修 建陵寺, 也有皇帝本人为其皇后修建陵寺的。因陵寺本身所处的特殊地理环 境, 所以陵寺的规格都比较高, 可以归属于皇家寺院之列 ${ }^{32)}$ 。张建林先生在 探讨唐代丧葬习俗中的佛教因素时亦有所涉及唐代陵寺 ${ }^{33)}$ 。

田有前调查了唐代昭陵附近的瑶台寺、高宗时期为河北祖陵修建的光业 寺、中宗定陵附近的定陵寺三处代陵寺遗址，探讨了其建立的时间、位置和 功能等。指出陵寺考古对于中国帝陵考古研究具有重要的推动作用，以后主要 任务在于搞清历代陵寺制度的演变、陵寺区的基本布局和遗迹、石刻分布和 保存现状等问题 ${ }^{34)}$ 。

\section{(七)、佛教石經的考古研究}

自北齐开始至明代，中国山东、河南、河北、山西、四川、重庆等地的佛 教信徒们，在山崖壁和石碑上刊刻了规模宏大数量惊人的佛经，为后人留下 了宝贵的文化财富。

1957年，对房山云居寺埋藏的石经进行了考古发掘，揭开了石经研究的序 
河 ${ }^{35)}$ 。1978年，宿白先生为第一届石窟寺考古研究生开设了“佛籍版本目录”的 课程，其中包括房山云居寺石经等内容，并带领学生进行了实地考察，成为 该领域的领路人。

其后, 以德国海德堡大学雷德侯教授为首的学术团队, 联合中国学者, 对中国各地石经进行了广泛的调查，并综合运用考古学和美术史的方法进行 研究，时间长达25年之久。期间，召开了多次国际学术讨论会，使石经的 研究成为中国佛教考古学的一项重要内容 ${ }^{30}$ 。

\section{結 語}

综上所述，几十年来，中国佛教考古尽管已经取得了很大的成绩，但存在 的问题还不少：石窟寺的分区、分期尚待全面开展、深入；跨区域和区域内 石窟寺之间的爸系以及石窟寺的综合研究较薄弱; 佛寺遗址多仅发掘出布 局，被完整发掘的佛寺遗址几乎没有；佛寺遗址的考古报告很少，远不能满 足研究者的需要, 也与中国千百年来佛寺数量远不相称；中外佛寺的比较研 究比较零散, 不够全面; 佛教宗派与佛寺形式的爸系尚不明晰 ; 佛寺与都 市、乡镇的爸系，等等，都值得去探究。

展望未来，我们对中国佛教考古的发展充满信心，其一是通过前辈们的努 力, 中国佛教考古学的框架体系已经大致构搭起来, 摸索出了一套行之有效 的理论方法, 已经成为中国考古学的一个分支 ; 其二, 通过几十年来的工 作, 已经积累起比较丰富的第一手考古资料, 为开展相爸研究提供了必要的 条件; 其三, 已经建立起老中青结合的专业人才队伍, 搭建了必要的学术平 台, 一些青年学者开始展露才能, 在研究领域占领了一席之地, 成为科研的 生力军: 随着中国经济的发展, 相矢器材设备的配备和科研经费的拨付已 经不再是束缚科研的瓶颈, 而是越来越成为发展的促进剂量和催化剂; 近十 
年来，佛教遗址考古越来越受到学界和社会的爸注和重视，调查和发掘的遗 址开始增多，大大地推动了佛教考古学的发展，相爸的研究越来越精细化、 系统化、科技化。由此可见，中国佛教考古学的发展前景无比美好。

\section{注釋：}

1）国家文物局编：《佛教石窟考古概要》，文物出版社，1993年。

2）李裕群《古代石窟寺》, 文物出版社, 2003年。

3）盛春寿等：《阿艾石窟》, 新疆美术摄影出版社, 2001年。

4)《表一, 西安出土北周石刻佛教造像统计表》, 中国社会科学院考古研究所：《古都 遗珍长安城出土的北周佛教造像》, 文物出版社2010年 ; 《表二, 隋唐长安城佛寺遗 存一览》, 龚国强：《隋唐长安佛寺研究》, 文物出版社2006年。

5) 中国社会科学院考古研究所著《北魏洛阳永宁寺- - 1979 1994年考古发掘报告》, 中国大百科全书出版社 1996年。

6）大同市博物馆胡平：《大同北魏方山思远佛寺遗址发掘报告》，《文物》2007年4 4 期。

7）夏名采《青州龙兴寺佛教造像窑藏》生活. 读书. 新知三联书店2004年。

8）中国社会科学院考古研究所、河北省文物研究所：《河北临漳县卦城遗址东魏北齐佛 寺塔基的发现与发掘》, 《考古》 2003年10期; 中国社会科学院考古研究所、河北 省文物研究所啙城考古队：《河北临漳县啮城遗址赵彭城北朝佛寺遗址的勘探与发 掘》, 《考古》2010年第7期 ; 中国社会科学院考古研究所：《河北临漳县䘧城遗址 北吴庄佛教造像埋藏坑的发现与发掘》, 《考古》2012年4期; 中国社会科学院考古 研究所、河北省文物研究所：《河北郢城遗址赵彭城北朝佛寺及北吴庄佛教造像埋藏 坑》, 中国文物信息网2013年03月28日。

9）刘景龙、李永强：《络阳龙门奉先寺遗址发掘简报》, 《中原文物》2001年2期。

10）成都市文物考古研究所、工怽市文物管理局：《四川工情崃龙兴寺-2005-2006年考古发 掘报告》文物出版社2011年。

11）中国社会科学院考古研究所：《唐长安青龙寺遗址》, 《考古学报》1989年2期。

12）中国社会科学院考古研究所：《唐长安西明寺遗址发掘简报》, 《考古》1990年1期。

13）中国社会科学院考古研究所、内蒙古第二工作队、内蒙古文物考古研究所：《内蒙古 巴林左旗辽上京皇城西山坡佛寺遗址考古获重大发现》, 《考古》2013年 第1期。

14）中国社会科学院考古研究所：《六顶山与渤海镇》, 中国大百科辞典出版社1997年。

15）《西藏萨迦寺考古发掘再获重要成果》, 《2007年中国重要考古发现》, 文物出版社 2008年。

16）中日共同尼雅遗迹学术考察队：《中日共同尼雅遗迹学术调查报告书》卷2, 中村印 
刷株式会社，1999年；张铁男、王宗否：《95年尼雅遗址93A35佛教寺院发掘简 报》、《1996年尼雅93A35号遗址中FA、FB、FC、FD发掘简报》，分别载于《新 疆文物》1998年第1期、1999年第2期。

17）中法联合克里雅河考古队：《新疆克里雅河流域考古考察概述》，《考古》1999年第 7 期。

18）中国新疆文物考古研究所、日本佛教大学尼雅遗址学术研究机构：《丹丹乌里克遗 址中日共同考察研究报告》, 文物出版社2009年 ; 刘国瑞、屈涛、张玉忠：《新疆 丹丹乌里克遗址新发现的佛寺壁画》, 《西域研究》2005年4期 ; 盛春寿、李军、 张铁男等：《新疆丹丹乌里克遗址新发现的佛寺壁画》，《边疆考古研究》第七 辑, 2008年。

19）中国社会科学院考古研究所新疆队： 《新疆和田地区策勒县达玛沟佛寺遗址发掘报 告》, 《考古学报》2007年第4期。

20）中国社会科学院考古研究所：《中国田野考古报告集：北庭高昌回鹘佛寺遗址》, 辽宁美术出版社，1991年。

21）杭㑆：《云冈第二十窟西壁珊塌的时间与县曜五窟最初的布局设计》, 《文物》 1994年10期。

22）徐苹芳: 《中国舍利塔基考述》, 《中国历史考古学论从》, 台北允晨文化1995年。

23）杨泓：《法门寺塔基发掘与中国古代舍利痤埋制度》, 《文物》1988年10期。

24）宿白：《东汉魏晋南北朝佛寺布局初探》, 《祝邓广铭教授九十华诞论文集》, 河北教育出版社，1997年；宿白：《隋代佛寺布局》，《考古与文物》1997年2期。

25）萧默：《敦煌建筑研究》, 文物出版, 1989年; 梁思成：《敦煌壁画中所见的中国 古代建筑》, 《梁思成文集》(一), 中国建筑工业出版社1982年 ; 龚国强 ; 《隋唐 长安佛寺研究》, 文物出版社2006年; 周绍良主编：《梵宫-一中国佛教建筑艺 术》，上海辞书出版社2006年。

26）戴俭：《禅宗寺院建筑布局初探》, 台北明文书局1990年。

27）梁白泉等：《佛教初传南方之路》, 文物出版社, 1993年; 阮荣春 : 《佛教南传之 路》, 湖南美术出版社, 2000年。

28）宿白：《京州石窟遗迹和 “凉州模式”》, 《考古学报》1986年第4期; 宿白：《平 城实力的集聚和 “云冈模式” 的形成与发展》, 《中国石窟・云冈石窟》 (一), 文 物出版社，1991年。

29）宿白：《青州城考略—- 青州城与龙兴寺之一》, 《文物》1999年第8期 ; 《龙兴寺 沿革一青州城与龙兴寺之二》, 《文物》1999年第9期 ; 《青州龙兴寺窝藏所出佛 像的几个问题 - - 青州城与龙兴寺之三》，《文物》1999年第10期。

30）金维诺：《中国古代佛雕：佛造像样式与风格》, 文物出版社2002年。

31）白文固：《宋代的功德寺和坟寺》, 《青海社会科学》2000年5期。

32）舟万里：《帝陵建寺之制考略》, 《西部考古》第一辑, 三秦出版社, 2006年。

33) 张建林： 《唐代丧葬习俗中佛教因素的考古学考察》, 《西部考古》第一辑, 三秦出 
版社, 2 006年。

34）田有前：《唐代陵寺考》, 《文博》2010年第4期。

35）中国佛教协会编：《房山云居寺石经》，文物出版社1978年版。

36）罗炤：《中国佛教考古学的开创者一宿白先生九秩华诞献词》, 《石窟寺研究》第 三辑，文物出版社 2012 年。 
Abstract

The current state ofresearchregarding Buddhist archaeology in China

\author{
Gong guogiang
}

The Institute of Archaeology, Chinese Academy of Social Sciences

Buddhism was introduced into China from the Eastern Han Dynasty , and after imput and imitation of Chinese Buddhism to the Three Kingdoms period of the first stage, it entered a rapid development, reform and gradually phase of chinese localization during the period of the Northern Dynasties and Tang Dynasty, until Yuan, Ming and Qing Dynasties, Buddhism has been completely localized.

Development of Buddhism in China, in addition to its intrinsic reason that on the basis of the traditional Indian Buddhist thought, then adapt and adjust to local conditions of China, but also because of the extenal factors that after the Eastern Jin Dynasty it got the strong support of the rulers and the general public.

Therefore, its rapid development can not only rival with Taoism, many times, it even pressure over the Taoism. It led that Buddhist stupa in the country as well as everywhere, and the level of the scale was constantly improved. a few can be compared with the palace buildings.

Meanwhile all the monks and nuns who constantly expanding forces have received unprecedented growth.

In the development process of the Buddhism, as the spread and interpretation medium of the Buddhist thought, Buddhist architecture and works of art played an irreplaceable important role. So Buddhist archaeological surveys, excavations and research have become an important 
part and branch of Chinese archaeology.

Chinese Buddhist archaeology is an archaeology branch that study with the Buddhist relics.

it is divided into two parts, cave temples, plains and mountain temple.

Currently, Chinese Cave Temple archaeology research is comparatively systematic and independent. It also got a lot of rich results. But the flat and mountain temple ruins of archaeological research is relatively weak, it still needs further development and improvement.

Although Chinese Buddhist archaeology have got great achievements. there are still many problems. Cave Temple partitions, staging still needs to be fully carried out. Relationships across regions and between regions within the cave temples and the comprehensive study of the cave temples are still relatively weak.

There are many Buddhist relics that only be excavated of the layout. There are almost no Buddhist temple ruins that were completely excavated. The reports of the Buddhist archaeological sites is so rarely that it can not fulfill with the needs of researhers.

Comparative Study of fragmented temple is not comprehensive enough. Buddhist sects and Buddhist temples in the form of relationship is not clear and its relationship with are

Cities, towns, etc. are worth to explore.

In recent years, more and more scholars are concerned and paying attention to the Buddhist archaeology.Surveys and excavations of the ruins began to increase.it greatly promoted the development of Buddhism-related archaeological research. Related researches become more sophisticated, systematic, and technological.

It shows that the development of Chinese Buddhist archeology is incomparably great. 


\section{중국불교고고학의 조사, 발굴과 연구}

번역 정대영 || 동양대학교 문화재발굴보존학과

\section{초록 -}

불교는 동한시기 중국으로 전래된 이래, 漢代와 三國, 兩晋시기의 불교수입과 모 방의 첫 단계를 거쳐, 북조시기에서 唐代에 이르러 발전, 개조, 중국화의 단계에 들 어간다. 이후, 송·원 · 명·청시기에 이르러 불교는 완전히 토착화되었다. 중국에서 의 불교 발전은 인도 전통불교 사상의 기초와 더불어 중국적 상황에 대한 적응과 조 절이라는 내재적인 요인이외에도 東晋이후 역대 통치자와 민중의 폭 넓은 지지라는 외부적인 요인으로 급격히 발전하였다. 불교는 중국 고유의 도교와 그 우월성을 두 고 다투기도 하였으며, 대부분의 시기에는 보다 더 우월한 지위에 있었다. 그러므로 사찰과 불탑은 전국에서 발전하였으며 규모와 등급도 왕궁건축과 비견될 만 하였다. 아울러 승려의 수도 증가하여 그 세력이 전례 없이 규모에 이르렀다. 이에 중국 각 시기의 정치, 경제, 문화, 예술 등 여러 방면에게 중요한 역사적 영향을 남김으로써 국내외 학계의 중요한 연구대상이 되었다.

불교의 발전 과정에서 불교건축과 불교예술품은 불교사상의 전파와 해석에 중요 한 실물 매개로 매우 중요한 가치를 지니고 있다. 중국에는 오랜 세월을 거친 수많 은 불교 사찰과 불탑, 석굴, 불교조각과 벽화, 불교문헌, 불교용품 등의 유적과 유물 이 남아 있다. 그러므로 불교고고학의 조사, 발굴, 연구는 중국 고고학의 중요한 구 성요소로 독립된 분과학문으로 자리매김하고 있다.

최근 중국불교고고학은 다양한 연구성과를 도출하였지만 많은 문제점도 남겨두 고 있다. 석굴사의 分區, 分期는 더욱 전면적으로 진행되어야 할 과제이다. 단일 지 역 안 밖의 석굴사 사이의 관계와 석굴사에 대한 종합적인 연구가 비교적 미약하다. 불사유적은 대부분 배치형태만이 발굴조사되었으며 전면적인 발굴조사가 진행된 불 사유적은 거의 없다. 불사유적에 대한 고고학 보고서도 많이 부족하여 연구자의 수 
요를 만족 시키지 못하고 있다. 유구한 중국역사에 비해 불사유적이 많지 않은 점도 지적할 수 있다. 국내외 불사에 대한 비교연구도 매우 산발적으로 진행되고 있다. 불교종파와 불사의 형식에 관한 연구도 아직 규명되지 않고 있다. 불사와 도시, 鄉 鎭과의 관계에 대한 연구도 과제로 남겨져 있다.

중국불교고고학은 불교유적과 유물을 연구대상으로 하는 고고학의 분과학문이며, 대체로 석굴사와 평지, 산지사찰로 양분할 수 있다. 그 가운데에서 불교조상을 비롯 하여 벽화, 비각, 석등(經幢), 불교용품 등은 고대사, 건축사, 미술사, 철학종교사, 문 헌학, 민족학, 과기고고, 문화교류사 등의 다양한 연구분야와 밀접한 관련을 가진다. 현재, 중국석굴사고고학의 연구는 비교적 체계적이고 독립적 영역을 확보하고 있으 며 다양한 성과들을 제시하고 있다. 평지와 산지사찰유적에 대한 고고학적 연구가 상대적으로 미약하며 앞으로 발전과 제고(提高)가 필요하다.

불교는 동한시기 중국으로 전래된 이래, 漢代와 三國, 兩晋시기의 불교수 입과 모방의 첫 단계를 거쳐, 북조시기에서 唐代에 이르러 발전, 개조, 중국 화의 단계에 들어간다. 이후, 송·원 · 명·청시기에 이르러 불교는 완전히 토착화되었다. 중국에서의 불교 발전은 인도 전통불교 사상의 기초와 더불 어 중국적 상황에 대한 적응과 조절이라는 내재적인 요인이외에도 東晋이후 역대 통치자와 민중의 폭 넓은 지지라는 외부적인 요인으로 급격히 발전하 였다. 불교는 중국 고유의 도교와 그 우월성을 두고 다투기도 하였으며, 대 부분의 시기에는 보다 더 우월한 지위에 있었다. 그러므로 사찰과 불탑은 전국에서 발전하였으며 규모와 등급도 왕궁건축과 비견될 만 하였다. 아울 러 승려의 수도 증가하여 그 세력이 전례 없이 규모에 이르렀다. 이에 중국 각 시기의 정치, 경제, 문화, 예술 등 여러 방면에게 중요한 역사적 영향을 남김으로써 국내외 학계의 중요한 연구대상이 되었다.

불교의 발전 과정에서 불교건축과 불교예술품은 불교사상의 전파와 해석 
에 중요한 실물 매개로 매우 중요한 가치를 지니고 있다. 중국에는 오랜 세 월을 거친 수많은 불교 사찰과 불탑, 석굴, 불교조각과 벽화, 불교문헌, 불교 용품 등의 유적과 유물이 남아 있다. 그러므로 불교고고학의 조사, 발굴, 연구는 중국 고고학의 중요한 구성요소로 독립된 분과학문으로 자리매김하 고 있다.

중국불교고고학은 불교유적과 유물을 연구대상으로 하는 고고학의 분과 학문이며, 대체로 석굴사와 평지, 산지사찰로 양분할 수 있다. 그 가운데에 서 불교조상을 비롯하여 벽화, 비각, 석등(經幢), 불교용품 등은 고대사, 건 축사, 미술사, 철학종교사, 문헌학, 민족학, 과기고고, 문화교류사 등의 다양 한 연구분야와 밀접한 관련을 가진다. 현재, 중국석굴사고고학의 연구는 비 교적 체계적이고 독립적 영역을 확보하고 있으며 다양한 성과들을 제시하고 있다. 평지와 산지사찰유적에 대한 고고학적 연구가 상대적으로 미약하며 앞으로 발전과 제고(提高)가 필요하다.

지금부터 중국불교고고학의 조사와 발굴에 대한 회고, 주요 연구과제 및 그에 관련 문제및 전망 등의 세 부분으로 나누어 간략히 서술하고자 한다. 학계 여러분의 지도와 지적을 부탁드린다.

\section{(-) 석굴사고고학의 조사와 발굴}

중국불교석굴은 인도에서 연원하며 기원 3세기에 출현하여 5세기에서 8 세기까지 융성하였으며 대체로 16 세기까지 축조되었다. 형태는 대부분 중심 탑주가 있는 塔廟窟과 중심탑주가 없는 佛殿窟, 僧房窟, 대형불상이 조각된 大像窟, 불단이 설치되어 있는 佛坛窟, 소형의 禅窟 등으로 나눌 수 있다1).

중국석굴사에 대한 고고학적 조사는 20세기 초와 1949년 이전에 외국학 자들의 조사와 발굴에서 시작하였다. 1893년에서 1931년까지는 영국의 스타 
인, 독일의 그 베델과 코크, 프랑스의 펠리오(Paul Pelliot), 스웨덴의 시렌 (Osvald Siren), 미국의 워너(Landon-Warner) 등 중국의 서북지역인 신강. 내몽고, 감숙 등지에서 불교사찰과 석굴을 조사하였다. 니야(尼雅), 루란(楼 兰), 미란(米兰), 단단우리크(丹丹乌里克), 热瓦克, 쿠차의 소파스(苏巴什), 두아두아-우쿠아(杜尔杜尔乌库尔), 투무쉬코(图木休克), 칠개성(七个星), 크 제얼(克孜尔), 베제클리크(伯孜克里克), 둔황(敦煌), 흑하(黑河) 등지의 불탑 과 사찰유적을 조사하여 대량의 불교조각품, 벽화, 문서 등의 불교유물을 반 출하였다. 이러한 자료들은 서방에서 출판되었으며 특히, 스타인의 『古代 和阗』(1907년)，『亚洲腹地考古记』(1928년)，『西域考古记』(1921 년), 펠리오의『伯希和西域探险记』, 코크의『高昌图录』등이 서양 학 자들에 의한 중국불교유적과 유물에 대한 연구열기를 일으키고 있다.

일본학자도 1902부터 1914년까지 大谷光瑞, 橘瑞超등에 의해 투루판(吐 鲁番), 루란(楼兰), 쿠처(库车), 허텐(和田)지역의 불교사찰유적을 조사, 발 굴하였으며 다량의 유물을 수집하였다. 1918년에서 1924년까지 常盘大定、 矢野贞은 중국 각지의 불교유적을 조사하였으며, 1925년에서 1939년 사이 에는 『支那文化史迹』，『支那佛教史迹』，『支那佛教史迹踏查记』 등을 출판하였다. 1938년에서 1941년 사이에는 水野清一, 长广敏雄 등이 중국에 서 조사, 발굴을 거쳐 1941년에『响堂山石窟』을 출판하였으며, 1951년에 는 『云冈石窟』16권을 출판하였다.

중국학자들에 의한 조사도 진행되었다. 1918년 진원(陈垣)은 비교적 체계 적으로 운강석굴을 조사하고 고증하여 『记大同武州山石窟寺』를 발표하였 다. 1932년에는 중국영조학사의 양사성 류돈정등이 운강석굴을 조사하여 『云冈石窟所表现的北魏建筑』을 발표하였다.

1949년 중화인민공화국 성립부터 1969년까지는 중국석굴사고고학의 성립 시기에 해당한다. 북경대학교 고고학과의 阎文儒, 宿白등은 석굴사찰과 관 련된 고고학 강의를 시작하여 석굴사고고학의 연구인력을 양성하였다. 아 
울러 주요 석굴이 소재한 敦煌莫高窟, 云冈, 龙门, 克孜尔, 响堂山, 麦积山 등지에 연구원과 연구소, 보관소를 설립하여 전면적인 고고학조사(측량, 등 록)와 발굴, 연구를 진행하였다. 甘肃성 永靖의 炳灵寺, 무위武威 천계산天 梯山, 경양북庆阳北 및 산서陕西지역의 석굴사찰 등이 새로 발견되었다. 1957년과 1961년에 북경대학교 고고학과는 향당산ㅁㅁㅁ미니과 둔황석굴에 대 한 조사를 진행하였다. 1957년, 북경대학교 숙백교수는 둔황문물연구소에서 『敦煌七讲』을 통해 석굴사의 조사와 연구에 고고학적 연구방법론을 제시 하여 중국석굴사고고학의 탄생을 알렸다.

1970 년 이후에서 지금까지는 중국석굴사고고학은 발전과 번성기에 해당 하며, 각 지역에서 고고학적 연구방법론에 의한 석굴사에 대한 발굴, 조사실 측과 종합적인 연구가 이루어지고 있다2).

1979년에서 1981년까지는 숙백에 의해 북경대학교 역사학과 석굴고고 조 사팀이 新疆克敄尔석굴을 조사, 기록, 실측하였으며, 일부 석굴에 대해서는 발굴조사와 수습조사가 이루어져 1997년에『新疆克孜尔石窟考古报告』출 판하였다. 이는 중국에서 출간된 최초의 석굴사찰에 대한 고고학 조사보고 서이다.

1980년 이후, 북경대학교 고고학과는 영하(宁夏)의 固原须弥山석굴, 하북 (河北)의 期郸南响堂석굴, 河西走廊의 초기 석굴, 용문석굴, 麦积山석굴의 일부 동굴에 대한 측량과 조사를 실시 하였다.

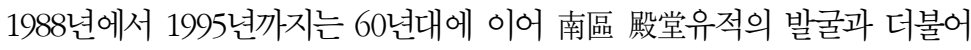
돈황연구원은 돈황막고굴 北區의 동굴 243기에 대해 전면적인 조사와 발굴 을 진행하여 북구 동굴의 성격과 내용에 대한 새로운 인식을 제시하여, 승방 굴(僧房窟), 禅窟(단실과 다실), 승방굴부설 선굴, 좌굴, 예불굴의 형태와 동 굴의 개착은 중간 부분에서 시작하여 양 측면으로 진행하였음을 밝혔다. 발 굴에 의해 북구의 동굴은 승려들의 생활, 거주, 수련의 공간이었으며 사후에 는 매장 장소였음을 밝혔다. 이러한 동굴의 성격은 북조시기부터 원나라시 
기까지 지속되었다. 2000년, 2004년을 전후하여 『敦煌莫高窟北区石窟』 1 , 2,3 권을 출판되었다.

1989년에서 1990년까지 산쟝(新疆)의 문물관련 부서에서 克孜尔석굴의 谷西區에 위치한 일부 석굴의 窟前유적에 대해 발굴조사를 실시하여 동굴 30 여기를 새로 발견하였으며, 일부 동굴의 교란관계를 통해 克孜尔석굴의 시기구분을 제시하였다.

1994년, 운강석굴보관소는 운강석굴 窟前유적을 부분 발굴하여 금동불상 의 잔편과 건축유적 4 기를 발굴하였다.

2002년에서 2006년 사이에 중국과학원 고고연구소와 산시성(山西省) 문 물기관이 연합 고고팀을 구성하여, 太原 서남쪽 용산(龙山)의 북쪽 봉우리에 서 북제시대에 창건되어 당대에 홍성한 동자사(童子寺)유적을 발굴하였다. 원락(院落), 월대, 본전, 불단, 석등, 승방 등의 유적이 조사되었으며, 본전은 정면 5 칸에 중앙불단은 이미 훼손되었으나, 불단에 세운 석주 5 기가 발견되 었다. 팔각 석등의 몸체와 상부는 당대 유물로 확인되었다. 최근에도 다수의 대형 석불상이 발견되었다.

1999년, 新疆 库车縣에서 70km 떨어져 있는 克孜里亚대협곡에서 阿艾석 굴이 새로이 발견되었으며 벽화와 漢文題記 등이 확인되었다3).

2008년, 낙양 용문석굴연구원과 북경대학 文博學院이 연합으로 용문석굴 의 擂鼓台석굴 窟前유적을 발굴조사하여 당대의 계단과 殿堂包石기단, 송대 의 造像題記와 건축기초, 당송시기의 窟前도로유적을 발견하였다.

1949년이후 중국석굴사고고학의 발전은 『敦煌研究』, 『敦煌学辑刊』, 『吐鲁番学研究』, 『石窟寺研究』등 학술간행물의 창간에서도 확인되며 연구자에게 전문적인 논문발표의 기반을 제공하였다. 아울러 다수 도록, 자 료집, 논문집, 논저 등도 출판되었다. 특히, 숙백의 1996년 『中国石窟寺研 究』와 2010년 『中国佛教石窟寺遗迹: 3至8世纪中国佛教考古学』은 가장 권위있는 저서로 손꼽힌다. 1980년 12월부터 일본 평범사(平凡社)는 중국문 
물출판사와 합작하여 발간하는 『中国石窟』시리즈 17 권을 출판하고 있다. 발간순서에 따르면, 『敦煌莫高窟』5권, 『巩县石窟寺』1권, 『克孜尔石 窟」 3 권, 『库木吐石窟』 1 권, 『永靖炳灵寺》 1 권, 『天水麦积山」 1 권, 『龙门石窟』2권, 『云冈石窟』2권, 『安西榆林窟』1권이 출간되었다. 각 권은 도면이 대체로 192-300장 수록되며 논문이 2-5편, 도판설명, 연표와 실 측도로 구성되어있다. 또한 각 석굴군의 내용 총록도 발표되었다. 또한, 『中国美术分类全集』，『中国壁画全集』，『敦煌莫高窟内容总录』， 『龙门石窟总录』，『须弥山石窟内容总录』，『敦煌石窟全集』，『俄罗 斯国立艾尔米塔什博物馆藏敦煌艺术品』의 출간은 관련 학술연구를 촉진시 켰다.

대규모의 국제학술대회가 개최되어 학술대회논문도 출간되었다. 「1994 요 敦煌学国际讨论会文集 ·石窟考古编」(甘肃民族出版社, 2000年), 「龙门石 窟一千五百周年国际学术讨论会论文集」(文物出版社，1996年)，「炳灵寺石 窟学术研讨会论文集」(由甘肃人民出版社，2003年）「「2004年石窟研究国际 学术会议论文集」(上、下册)(上海古籍出版社，2006年)，「云冈石窟国际学 术研讨会论文集」(保护卷, 研究卷)(文物出版社, 2006年)등이 출간되었다.

그 외에는 둔황연구원의 『敦煌研究文集·敦煌石窟考古篇』, 난주대학교 둔황학연구소, 麦积山석굴예술연구소의『大水麦积山石窟研究论文集』, 란주대학교 둔황학연구소의 『永靖炳灵寺石窟研究文集』 등의 논문집도 출 판되었다.

이상과 같은 다수의 도록과 학술논문집의 출판은 중국석굴사고고학 연구 의 폭과 깊이를 반영하고 있다. 


\section{(二) 평지와 산지 불교사찰 유적의 고고조사와 발굴}

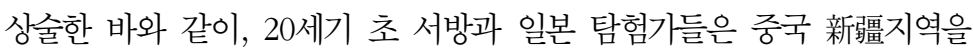
중심으로 불교사찰유적에 대한 조사와 발굴을 진행하였다.

비교적 이른 시기에 중국불교사찰유적을 조사한 중국학자는 황문빈으로 1927년, 1930년, 1943년에 걸쳐 3차례의 新疆塔里木盈地지역 불교사찰유적 을 조사하였으며，『罗布淖尔考古记』(1948)，『吐鲁番考古记』(1954, 1958)，『塔里木盆地考古记』(科学出版社，1958年）、西北史地论从』 등 을 출간하였다.

1937년 건축사학자 梁思成과 林徽因, 莫宗江등은 산서성 오태산(五台山) 조사에서 당대 불광사 본전을 발견하였다. 또한 양사성과 류돈정은 운남, 사 천 등지의 40 여 개 현을 조사하여 고대 불교사찰과 고대건축을 조사하였으 며, 다수의 고건축모형도를 제작하여 영조학사의 간행물에 『我所知道的唐 代佛寺与宫殿』，『薊县独乐寺山门考』，『云岗石窟中所表现的北魏建 筑」 등의 논문을 발표했다. 1944년 양사성은 『中国建筑史』 를 집필하였 다. 1949년 이후 평지와 산지사찰에 대한 고고학적 조사는 비록 체계적이지 않지만, 지속적인 발견과 발굴이 이루어져 영향을 미쳤다. 아래에서는 지역 과 시대순서에 따라 서술하겠다.

\section{1. 중원지역}

（1）佛寺塔基의 地宮, 탑 내부 天宫의 고고학 발견

1964년 이래, 전국적으로 불교사찰의 塔基 地宮과 탑 내부 天宮에서 사리 가 봉안된 사리구와 공양품이 출토되었으며 이들은 대부분 명확한 기년을 가지고 있다. 구체적인 내용은 아래의 표와 같다. (지역 순서에 따라) 


\begin{tabular}{|c|c|c|c|c|c|}
\hline 번호 & 발견지점 & $\begin{array}{l}\text { 발견 } \\
\text { 시기 }\end{array}$ & 주요출토유적,유물 & 년대 & 비고 \\
\hline 1 & 河北定縣城塔基 & 1964 & $\begin{array}{l}\text { 石函、琉缡鉢、銅錰和琉缡葫芦瓶、 } \\
\text { 七宝飾物珠宝 }\end{array}$ & 北魏 481年 & (考古) 66.5 \\
\hline 2 & 河南洛陽北永宁寺塔基 & 1979 & 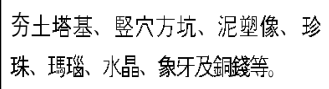 & $\begin{array}{c}\text { 北魏熙平元年 } \\
\text { (526年) }\end{array}$ & 《考古〉 81.3 \\
\hline 3 & $\begin{array}{l}\text { 陕西西安東效清禪寺隋舍利 } \\
\text { 墓 }\end{array}$ & 1986 & 墓志 灰陶罐、供養珠玉宝飾物 & $\begin{array}{c}\text { 大陡開皇9年 } \\
\text { (589年) }\end{array}$ & $\begin{array}{c}\text { 《考古与文物》 } 88 . \\
1\end{array}$ \\
\hline 4 & 山東平陰陵舍利宝塔石函 & 1982 & 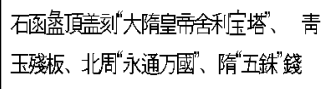 & $\begin{array}{c}\text { 隋文帝仁壽年間 } \\
(601 \sim 604 \text { 年 })\end{array}$ & 〈考古〉 86.4 \\
\hline 5 & 陕西䧽隋门神德寺舍利塔基 & 1969 & 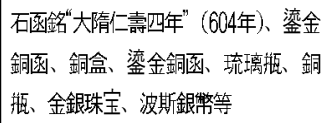 & 隋代 & 侤古〉 74.2 \\
\hline 6 & 山西太原龍泉寺塔基地宮 & 2008 & 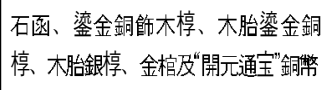 & 武居時期 & 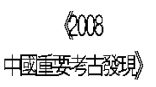 \\
\hline 7 & 四川成都唐代塔基地宮 & 1980 & 石函、銅棺、銀鋯、“五銖”錢 & 唐代 & $\begin{array}{c}\text { 《考古与文物〉 } \\
83.3\end{array}$ \\
\hline 8 & 江蘇句容行香朱隍村唐代塔基 & 1975 & 地宮、鐵函、銅楟、銀婷、小鉽棺 & 唐代早期 & 〈考古〉 82.2 \\
\hline 9 & 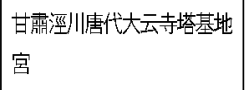 & 1964 & 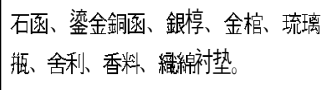 & 武周時期 & (文物) 66.3 \\
\hline 10 & 陕西周至縣仙游寺法三塔 & 1988 & $\begin{array}{l}\text { 塔身、地宮，墢現石碑、石函、蓅金 } \\
\text { 銅棺、舍利 } \\
\text { 舍利塔下釷》，唐代的《仙游寺舍利 } \\
\text { 塔銘》 }\end{array}$ & 唐代 & 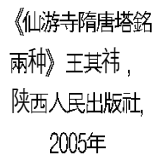 \\
\hline 11 & 河南登封法王寺塔基地宮 & & 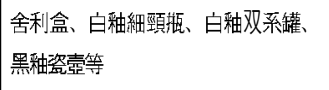 & 晚唐 & $\begin{array}{l}\text { 《2000中國重要考 } \\
\text { 古發現》 }\end{array}$ \\
\hline 12 & $\begin{array}{l}\text { 陕西臨潼唐代慶山寺塔基地 } \\
\text { 宮 }\end{array}$ & 1985 & 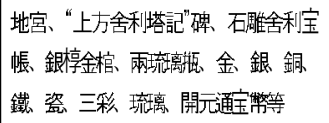 & 唐開元29年 & 《博》 85.5 \\
\hline 13 & 陕西扶風法門寺塔基地宮 & 1987 & 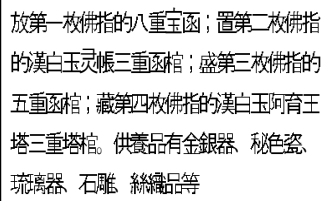 & $\begin{array}{c}\text { 唐咸通15年 } \\
(874 \text { 年 })\end{array}$ & $\begin{array}{l}\text { 《法門寺考古發掘 } \\
\text { 報告》， } \\
\text { 文物出版社107年 }\end{array}$ \\
\hline
\end{tabular}




\begin{tabular}{|c|c|c|c|c|c|}
\hline 번호 & 발견지점 & $\begin{array}{l}\text { 발견 } \\
\text { 시기 }\end{array}$ & 주요출토유적,유물 & 년대 & 비고 \\
\hline 14 & $\begin{array}{l}\text { 山東惠民出土唐末五代定光 } \\
\text { 佛舍利棺 }\end{array}$ & 1972 & $\begin{array}{l}\text { 定光佛( (然灯佛)舍利棺，石楟、鐵 } \\
\text { 棺、數栈“開元通宝”錢 }\end{array}$ & 唐末 & 《文物》 87.3 \\
\hline 15 & 甘寢灵台五代舍利地宮 & 1957 & 石棺、漆盒、琉缡桼、墓志、銅鏡 & 五代 & (文物) 83.2 \\
\hline 16 & 浙江杭洲雷峰塔基地宮 & $\begin{array}{c}2000 \\
-200 \\
1\end{array}$ & 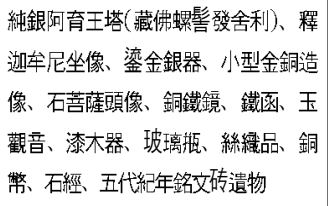 & 五代 & $\begin{array}{c}2001 \\
\text { 中國重要考古被覞) }\end{array}$ \\
\hline 17 & 江蘇䱶利虎丘北宋云岩寺塔 & 1957 & 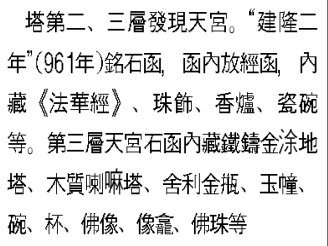 & 北宋 & $\begin{array}{l}\text { 蘇忡虎丘塔出土 } \\
\text { 文物》， } \\
\text { 文物出版58年 }\end{array}$ \\
\hline 18 & 河北定縣兩座宋代塔基 & 1969 & 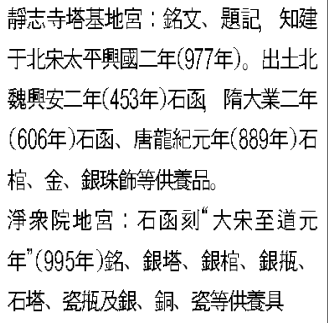 & 北宋 & 《文物 $\rangle 72.8$ \\
\hline 19 & $\begin{array}{l}\text { 河南密縣原法海寺旧址上, } \\
\text { 發現了北宋塔基地宮 }\end{array}$ & 1966 & 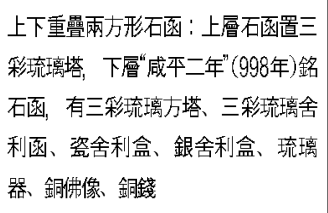 & 北宋 & 《文物) 72.8 \\
\hline 20 & 江蘇薊利|宋瑞光寺舍利寺塔 & 1978 & 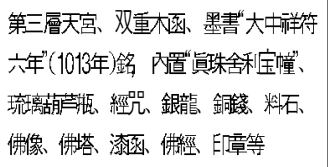 & 北宋 & $\begin{array}{c}\text { (文物) } 79.11 \text {; } \\
86.9\end{array}$ \\
\hline 21 & $\begin{array}{l}\text { 江蘇蔪云港海清寺北宋阿育 } \\
\text { 王塔 }\end{array}$ & & 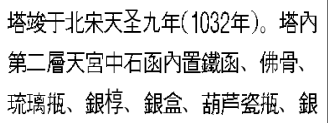 & 北宋 & 《文物》 81.7 \\
\hline
\end{tabular}




\begin{tabular}{|c|c|c|c|c|c|}
\hline 번호 & 발견지점 & $\begin{array}{l}\text { 발견 } \\
\text { 시기 }\end{array}$ & 주요출토유적,유물 & 년대 & 비고 \\
\hline & & & 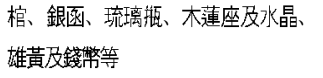 & & \\
\hline 22 & 浙江瑞安北宋慧光塔 & 1966 & 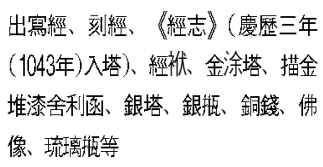 & 北宋 & 文物》 73.1 \\
\hline 23 & 浙江金華北宋万佛塔塔基 & 1956 & 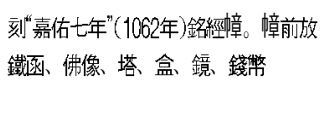 & 北宋 & $\begin{array}{l}\text { 《金華万佛塔出土 } \\
\text { 文物》，文物出版 } \\
\text { 形 } 58 \text { 年 }\end{array}$ \\
\hline 24 & 上海松江北宋興敉寺塔地宮 & 1974 & $\begin{array}{l}\text { 北宋熙宁、元佑年間 }(1068-1093 \text { 年) } \\
\text { 所建。出土石函、唐宋銅錢、銅坐 } \\
\text { 佛、漆函、銅卧佛和大小銀函、銀 } \\
\text { 珠、沉香、佛牙、舍利子等 }\end{array}$ & 北宋 & 〈考古〉 83.12 \\
\hline 25 & $\begin{array}{l}\text { 江鱝鎮江甘露寺宋代鐵塔地 } \\
\text { 呂 }\end{array}$ & 1960 & 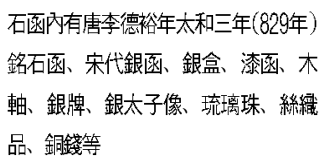 & 唐宋 & 〈考古〉 61.6 \\
\hline 26 & 山東濟宁北宋鐵塔 & 1973 & 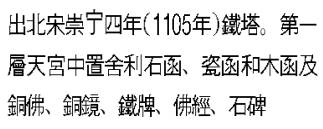 & 北宋 & 文物) 87.2 \\
\hline 27 & 云南大理崇圣寺千尋塔 & 1979 & 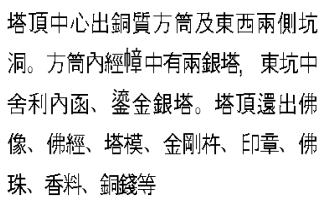 & $\begin{array}{c}\text { 大理國時期 } \\
(1000 \sim 1160 \text { 年 })\end{array}$ & 《考古學報》 81.2 \\
\hline 28 & $\begin{array}{l}\text { 浙江麗水碧湖鎮南案塔基地 } \\
\text { 宫 }\end{array}$ & 1960 & $\begin{array}{l}\text { 出有佛經、銅佛、銅鏡、砖刻、碑 } \\
\text { 刻、琉缡珠、錢幣、瓷残器及佛牙等 }\end{array}$ & 南宋 & 文物〉 63.3 \\
\hline 29 & 北京順義縣遼淸光舍利塔基 & 1963 & 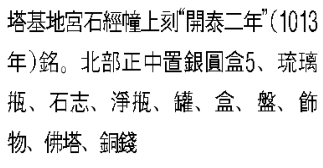 & 遼 & 〈文物〉 64.8 \\
\hline 30 & 吉林農安万金泷嘹代塔基 & 1970 & 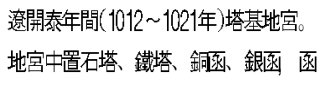 & 遼 & 《文物》 73.8 \\
\hline
\end{tabular}




\begin{tabular}{|c|c|c|c|c|c|}
\hline 번호 & 발견지점 & $\begin{array}{l}\text { 발견 } \\
\text { 시기 }\end{array}$ & 주요출토유적,유물 & 년대 & 비고 \\
\hline & & & 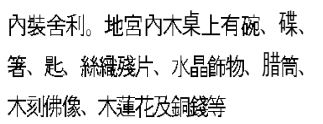 & & \\
\hline 31 & $\begin{array}{l}\text { 內蒙古宁城武官營子遧塔地 } \\
\text { 宮 }\end{array}$ & 1954 & 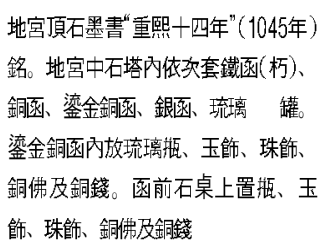 & 遼 & 〈考古〉 64.11 \\
\hline 32 & 北京房山北奠村遼塔基地宮 & 1977 & $\begin{array}{l}\text { 地宮中石函刻“重熙二十年”(1051年) } \\
\text { 銘。函內放石佛像、瓷碟、銅碗、 } \\
\text { 赽、鏡、銀碗、碟、筯、佛幡、幡 } \\
\text { 架、宝花和水晶珠及舍利。在地宮石 } \\
\text { 板盖上立石幢 }\end{array}$ & 遼 & 〈考古〉 80.2 \\
\hline 33 & 遼宁朝陽㙩代北塔 & 1986 & 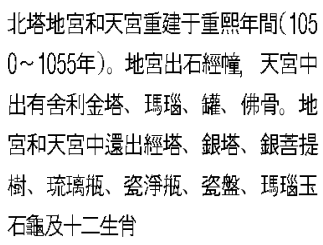 & 遼 & 伩物 92.7 \\
\hline 34 & 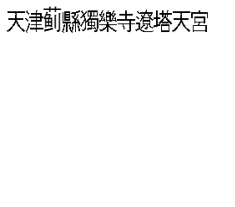 & 1983 & 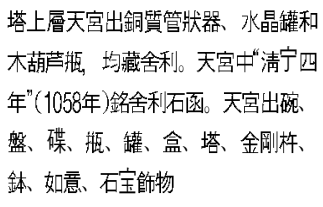 & 遼 & 《考古學報》89.1 \\
\hline 35 & 遼宁沈陽遼崇壽寺白塔 & 1956 & 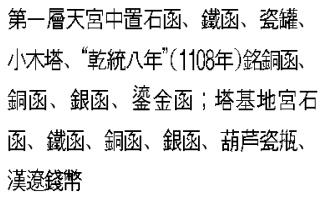 & 遼 & $\begin{array}{l}\text { 《文物參考資料 } \\
57.8: \\
\text { (考古通訊) } 57.6\end{array}$ \\
\hline 36 & 河北易縣潦浮覺寺舍利地宮 & 1977 & 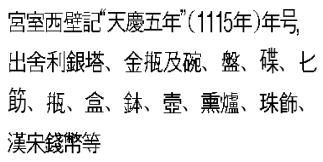 & 遼 & (文物) 86.9 \\
\hline
\end{tabular}




\begin{tabular}{|c|c|c|c|c|c|}
\hline 번호 & 발견지점 & $\begin{array}{l}\text { 발견 } \\
\text { 시기 }\end{array}$ & 주요출토유적,유물 & 년대 & 비고 \\
\hline 37 & 山西鷹縣遼佛宮寺木塔 & 1974 & $\begin{array}{l}\text { 塔第二、四層主像凹槽內均發現銀 } \\
\text { 盒，內盛七宝与佛牙。第四層主佛凹 } \\
\text { 槽丙放大量經参 }\end{array}$ & 遼末金初 & 文物 82.6 \\
\hline 38 & 浙江崇德崇福寺西塔塔頂 & 1955 & 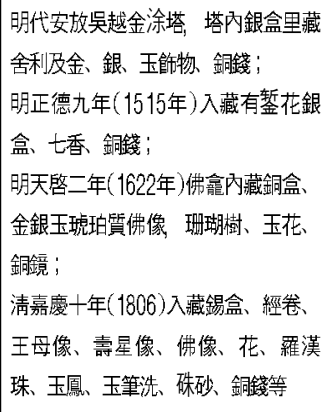 & 明、清 & $\begin{array}{c}\text { 文物參考資料》 } \\
56.1\end{array}$ \\
\hline 39 & $\begin{array}{l}\text { 山東刵城鐵塔塔基地宮中明 } \\
\text { 代舍利器具 }\end{array}$ & 1973 & $\begin{array}{l}\text { 鐵塔北宋晚期建，其地宮內發現明代 } \\
\text { 重㾤的石函、銀函及全錢慗 }\end{array}$ & 明代 & (考古) 87.2 \\
\hline 40 & $\begin{array}{l}\text { 江蘇南京秦㴤區中華門外 } \\
\text { 雨花路東儧瓡恩寺塔基地宮 }\end{array}$ & $\begin{array}{l}2007- \\
2010\end{array}$ & 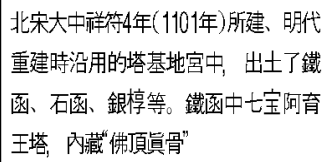 & \begin{tabular}{|c} 
明代永樂至宣德 \\
年間
\end{tabular} & 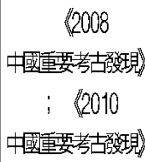 \\
\hline
\end{tabular}

상기 표와 같이 섬서성 법문사, 절강성 항주 雷峰塔, 강소성 남경 대보은 사탑의 지궁에서 출토된 사리구는 모두 당대, 오대, 명대황실에서 공양한 사 리와 사리기로 등급이 높고 공예가 정교하다. 이 발견은 사회적 강렬한 반 응을 불러일으켰다.

(2) 佛像窝藏, 佛像群의 발견

최근 하북성 ⿱ㅏㅌ城, 曲阳, 하남성 洛阳, 섬서성 서안 등지에서 불상窑藏과 불상군이 지속적으로 발견되어 그 수량이 많아 본 고에서는 일일이 열거하지 않고 서안지역에서 출토된 돌제, 금동, 泥佛의 사례를 소개하고 자 한다4). 


\begin{tabular}{|c|c|c|c|c|c|}
\hline 序号 & 出土地点 & $\begin{array}{l}\text { 出土 } \\
\text { 時間 }\end{array}$ & 佛集种類數量 & 時代 & 備注 \\
\hline 1 & 蓮湖區大土門村南 & 1957年 & $\begin{array}{l}\text { 泥塑像、石像數百票，部分造像刻有“大唐善 } \\
\text { 業尼” }\end{array}$ & 唐 & 金城坊開善尼寺遗址 \\
\hline 2 & $\begin{array}{l}\text { 西安東郊新城區電厂路 } \\
\text { 龍䒜村北側 }\end{array}$ & 1959年 & 石像空藏佛像10 & 唐 & 長樂坊大安國寺 \\
\hline 3 & $\begin{array}{l}\text { 未央區漢城街道辦事處 } \\
\text { 范家堡 }\end{array}$ & 1971 & 佛和菩薩像3 & 北周 & \\
\hline 4 & $\begin{array}{l}\text { 未央區六村堡街道辦事 } \\
\text { 處東席村 }\end{array}$ & 1973 & 菩薩像1、四面造像碑1 & 北周 & \\
\hline 5 & 维荅豆小寨佳道東八里村 & 1974年 & 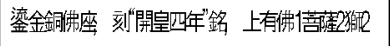 & 隋 & 昌樂坊 \\
\hline 6 & $\begin{array}{l}\text { 未央區草灘街道辦事處 } \\
\text { 李家街村 }\end{array}$ & 1975 & 佛俞像17 & 北周 & \\
\hline 7 & $\begin{array}{l}\text { 未央區六村堡街道獥事 } \\
\text { 中官亭村 }\end{array}$ & 1982 & 立佛像2、孉音立像(保定5年題記)1 & 北周 & \\
\hline 8 & $\begin{array}{l}\text { 沣鎘四路以南、勞動南 } \\
\text { 路以西 }\end{array}$ & $\begin{array}{c}1982.19 \\
86\end{array}$ & 石造像窗藏，附近出百件善業泥像 & 唐 & 礼泉寺 \\
\hline 9 & $\begin{array}{l}\text { 未央區未央宮辦事處大 } \\
\text { 劉侅村西 }\end{array}$ & 1984 & 佛頭像2 & 北周 & \\
\hline 10 & 蓮湖區空軍通訊學院 & & 立佛像2 & 北周 & \\
\hline 11 & $\begin{array}{l}\text { 蓮湖區西稻門西北空軍 } \\
\text { 通訊學院 }\end{array}$ & 1984等 & 出北朝、隋唐石像窝藏 出佛、菩薩石像32 & & $\begin{array}{c}\text { 金城坊樂善尼寺 } \\
\text { (溫國寺) }\end{array}$ \\
\hline 12 & 西安大南門外冊家村南 & 1985 & 窝藏坑石佛造像11 & 隋 & 崇義坊正覺寺 \\
\hline 13 & $\begin{array}{l}\text { 蓮湖區桃園街道辦事處 } \\
\text { 原西安民航机場 }\end{array}$ & 1986 & 觀音像1、釋伽二俅浩像䡒1、佛頭2 & 北周 & \\
\hline 14 & $\begin{array}{l}\text { 未央區漢城街道辦事處 } \\
\text { 西查村 }\end{array}$ & 1992 & 觀音像3 & 北周 & \\
\hline 15 & $\begin{array}{l}\text { 灞橋區紅旗街道辦事處 } \\
\text { 湾子村 }\end{array}$ & 2004 & 立佛像占，佛座4 & 北周 & \\
\hline 16 & $\begin{array}{l}\text { 西安未央區中查村西北 } \\
\text { 北周長安城宫城之南 }\end{array}$ & 2004 & 造像31件，包括立像 坐像、立菩隡像等 & 北周 & 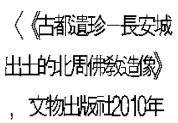 \\
\hline
\end{tabular}




\begin{tabular}{|c|c|c|c|c|c|}
\hline 序号 & 出土地点 & $\begin{array}{l}\text { 出土 } \\
\text { 時間 }\end{array}$ & 佛㑇种類數量 & 時代 & 備注 \\
\hline 17 & $\begin{array}{l}\text { 未央區六村堡街道辦事 } \\
\text { 處贖寨村 }\end{array}$ & 2007 & 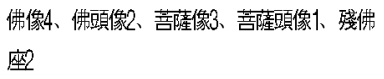 & 北围 & \\
\hline
\end{tabular}

(3) 불교사찰유적

상기한 불탑지궁(地宫)과 불상군의 고고학 발견 외에도 불교사찰유적의 고고학 조사와 발굴은 점차 주목받고 있으며 최근 새로운 발견도 증가하고 있다.

1963년과 1979년에서 1981년까지 중국과학원고고연구소는 하남성 낙양시 에 소재한 东汉, 魏시기 洛阳故城내의 永宁寺유적을 발굴, 조사하였다. 조 사에 의하면, 사원의 평면은 장방형이며 남북 $305 \mathrm{~m}$, 동서 $260 \mathrm{~m}$ 이다. 탑의 기단은 사원의 중앙부에 위치하며 평면은 방형이고 기단 네 면은 극므을 이 용하여 축조하였으며 모두 계단을 설치하였다. 탑의 북쪽에는 비교적 넓은 판축의 기단유적이 남아 있으며 正殿으로 추정된다. 발굴조사를 통해 이는 중국 초기 불교사찰 전전후탑(前塔后殿) 배치의 전형적인 사례로 추정된다. 사찰에서는 다량의 석제 조각과 기와, 와당, 소조상의 잔편들이 출토되었다. 소조상의 잔편은 대형과 소형의 두 가지로 구분되는데 대형은 비교적 적고 대체로 佛과 보살상이다. 소형은 300여기가 출토되었으며 대부분은 벽면에 부착된 '影塑”이고, 대부분 비천, 보살, 비구 및 세속 공양인상, 높은 모자와 큰 신발을 착용하고 넓은 띠를 매고 있는 상류 인물 및 侍從. 文吏와 무사로 조형이 정교하며 생동감이 있다5).

1981년 산시성 대동시 박물관은 대동시 동북의 方山 남쪽에서 북위시기 불사유적을 발굴하였다. 북위, 遼, 金, 明淸시기의 문화층이 확인되었으며 북위시기의 山門, 회랑식 塔基, 불전, 선방 등이 발굴되었으며 북위시기 莲 
花化生와당을 비롯한 불상 잔편들이 출토되었다6).

2010년 산서성 운강석굴연구원은 비교적 완전한 형태의 북위시기 사찰유 적을 발견되어 北廊房, 东廊房, 西廊房, 南廊房, 塔基, 砖瓦窑유적이 발굴되 었다. 2011년에는 사원에서 $400 \mathrm{~m}$ 떨어진 석굴의 상부에서 북위시기의 석조 구조의 塔基가 발견되었다. 불탑건축의 구조는 기초, 기단, 석탑하부건축의 3 부분으로 구분된다. 塔基 평면은 정방형에 가까우며 남향이고 塔基의 4 면 에는 석제의 벽체를 축조하였다. 塔基의 남면에 동서방향의 동쪽 계단과 서 쪽 계단이 각 하나씩 설치하였으며, 동, 서 방향으로 탑에 오를 수 있다. 석 탑의 하부건축은 塔芯과 塔芯을 둘러 싼 회랑의 두 부분으로 구성되어 있다. 塔身 정중앙에 상-하를 연결하는 찰주가 있다. 이러한 발굴조사의 내용은 북위시기 用道元의 『水经注』에서 묘사된 운강석굴의 '山堂水殿, 煙寺相望” 의 광경에 비견된다.

1996년 10월 산동성 청주(青州)의 용흥사(龙兴寺)에서 佛像窝藏이 발견 되었다. 窝藏의 동서 길이는 $8.6 \mathrm{~m}$, 남북 너비는 $6.7 \mathrm{~m}$, 깊이는 $3 \mathrm{~m}$ 에 이른다. 불상 400 여 기가 출토되었으며 년대는 대부분 남북조 시기에 해당한다7).

2002년 하북성 临漳县의 赵彭城㸃城유적에서 북조시기의 佛寺塔基 유적 이 발굴되었다. 이후 불탑 주변에 대한 발굴조사가 진행되어 2011-2012년에 는 중심축선의 북쪽에서 대형의 건축유적과 東南院大型建築유적을 발굴하였 다. 이를 통해 사찰의 가람배치에 대한 중요한 성과를 얻었으며 ㅊ㐅ㅊ회히

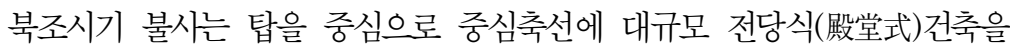
축조한 다원락식(多院落式) 배치의 대규모 불사임이 증명되었다. 2012년 1 월에는 업남성의 동곽성구(㸃南城东郭城区)와 북오장촌(北吴庄村) 북쪽에 서 대형의 불상매장갱이 발굴되었다. 출토된 불상의 수량이 2895기에 이르 며 대부분 채회(彩绘)와 改金흔적이 확인되었으며 시기는 대체로 북위, 동 위, 북제, 북주, 수당에 이른다. 지금까지 알려졌던 출토수량 최대의 불상매 장갱이라고 볼 수 있다8). 
1997년부터 2000년까지 냑양시문물관리국, 용문석굴연구소는 이탈리아의 中遠東연구소, 나폴리대학교 동방문화연구소와 합작으로 낙양용문석굴 서쪽 의 당대 奉先寺유적을 발굴조사 하였다. 발굴조사에서 전당지와 水道유적 및 자기와 석각조상등이 발견되었다9).

2005년부터 2006년까지 四川省 成都市 I队崃县의 당송시기 龙兴寺유적이 발굴조사되었다. 주거지를 비롯하여 방형의 전탑기단과 북송시기의 나한전, 우물, 불상갱, 무덤등의 유적이 조사되어 석각조상과 석등, '大中九年'(855년) 명의 천왕상, 석각경판, 유리부재, 도자기, 동경, 화폐 등이 대량으로 출토되 었다10).

1973년부터 1980년까지 중국과학원고고연구소는 서안시 철루묘촌(铁炉 庙村)의 당대 밀교의 祖庭인 청룡사유적을 발굴조사하였다. 발굴을 통해, 동 서병렬의 庭院 두 개 및 사원의 북대문이 발굴조사되었다. 서쪽에 있는 庭 院은 회랑을 갖춘 塔院구조로 中三門, 목탑, 불전 및 4 면 회랑의 구조이며, 東院에서는 초기와 말기의 전당지가 발굴조사되었다. 전당지 주망갱(柱网 坑)의 배열은 매우 정연하였다11).

1985년과 1992년 중국과학원고고연구소는 서안시 비림구 백묘촌(西安市 碑林区白庙村)에서 당장안성의 유명사찰인 서명사(西明寺)유적을 발굴조사 하였다. 두 차례의 발굴조사를 통해 만 평방미터 유적이 조사되어 사찰 동 부의 정원 3개로 구성된 편원(偏院)유적이 확인되었으며 前院의 前殿, 中殿, 北殿, 4 면회랑의 담장, 정원, 水道洷井, 도로를 비롯하여 남부중앙의 夾道등 이 확인되었다. 석등을 비롯하여 금동불상, 석불상, 陶佛像, 비각의 잔편, 석 제 차연(石茶碾), 자기 완(瓷碗), 자기 柱子, 벼루, 玻璃鱼饰 및 '건원중보' (乾元重宝), ‘개원통보' (开元通宝)등의 화폐유물들이 출토되었다12).

2011년부터, 내몽고문물고고연구소는 중국사회과학원 고고연구소 내몽고 2 팀과 공동으로 요상경연합발굴대를 구성하여 내몽고 적봉시 파림좌기 임동 진 동남쪽에 위치한 요상경 황성 의 서산파(西山坡) 사원유적을 발굴조사 하 
였다. 사원은 장방형院落형태로 4 면은 담장이며 중심축선에는 대규모의 육 각형 塼木혼합구조의 불전과 좌우대칭으로 배치된 소형의 육각형전탑, 대전 앞의 소형 건축유적과 광장이 확인되었다. 유적에서는 소조 인면상(얏ㅅ살 塑人面像)을 비롯하여 석상(石像), 부도(石经幢), 동경, 철기, 도자기 등의 유물들이 다량으로 출토되어 遼代의 고고학, 역사, 불교, 건축연구에 중요한 실물자료들을 제공해 주고 있다13).

\section{2. 변방(边疆)지역}

1957년 황문빈(黄文盿)은 제4차 신강(新疆)조사에서 古城과 사원유적을 조사하였으며 고고연구소에 의해 자료가 정리되어 1983년 『신강고고발굴 보고서』가 출간되었다.

1963년과 1964년에는 중국과학원고고연구소에 의해 黑龙江 宁安市 渤海 镇에 위치한 발해시기 상경 용천부龙泉府유적이 발굴조사되어 1-9호로 명명 된 불교사원 9곳이 확인되었다. 조사 내용에 의하면, 동성서쪽에서 첫째 열, 북쪽에서 두번째 방(坊) 서쪽의 1호 불교사찰이 가장 규모가 크며 본전, 穿 廊와 동,서실 3 부분으로 구성되어 ‘凸’자형의 전각과 같이 형태이며 3 부분의 기단은 서로 연결되어 있다. 主殿의 동서 길이는 $23.68 \mathrm{~m}$, 남북 길이는 $20 \mathrm{~m}$ 이다. 도성 밖 북쪽에 위치하는 9호사원은 장방형의 독립적인 불전으로 정 면 5 칸, 측면 4 칸에 외부는 회랑구조이며 전각 내부의 中心坛座는 减柱형식 이다14).

1959년과 1986년에는 숙백에 의해 2차례에 걸쳐 티베트의 라사、山南、 日喀则、江孜지구에 대한 조사가 이루어졌다. 그는 조사된 기록과 도면들을 고고유형학적 방법론에 의거하여 티베트 불교사찰의 평면 배치와 ㄱ⼋색연구 를 진행하였다. 이후 그는 「西藏拉萨地区佛寺调查记」,「西藏山南地区 
佛寺调查记」,「西藏日喀则地区寺庙调查记」 등의 연구논문을 발표하였 으며 1996년 「藏傳佛敉寺院考古」를 출간하여 티베트불교고고연구의 기초 를 다졌다.

1985년 국가문물국은 티베트 阝⿹⼝ㅗ지역에 대한 문물조사를 실시하였으며 집중적인 연구대상은 古格王國시기 도성인 札不让을 중심으로 古格시기 건축 유적에 집중되었다. 조사성과는 1991년 출판된 《古格故城》에 수록되었다.

2005년부터 2007년까지 섬서성 고고연구소와 티베트 문물보호연구소는 티베트 萨迦寺의 北寺유적에 대한 전면적인 조사와 일부 구간에 대한 발굴 조사를 실시하였다. 萨迦南寺羊马城의 성벽 및 해자, 北寺의 得确颇章유적, 乌孜大殿유적 및 塔林의 일부 塔基에 대한 발굴조사를 진행하였다. 또한, 萨迦北寺의 건축유적인 桑阿德吉林、东热布拉康유적에 대한 현지조사와 발 굴조사가 진행되었다15).

新疆楼兰、尼雅、交河故城등 실크로드상의 대규모유적에서 대부분 불교 건축유적이 발견되었으며 주로 “木骨泥墙法”에 의해 불탑, 사찰, 불당과 불 단의 4 가지 유형이 축조되었다.

1995년 신장문물고고연구소와 일본의 관련기구는 중일 尼雅유적학술고찰 대를 조직하여 신장民丰县 사막에서 위진시기의 尼雅불교사원유적을 조사 하였다. 사원 남쪽에는 불전(FS)이 위치하며, 서쪽에는 선방과 강경당(FD)이 있으며 북쪽에는 회랑을 갖춘 주거지가 있다. 중앙은 약 $500 \mathrm{~m}^{2}$ 면적의 광장 이 위치하며 불전, 선방, 강경당으로 구성된 완정한 불교사원이다. 사원유적 에서는 목조천인상을 비롯하여 부처와 보살상이 그려진 벽화의 잔편들이 출 토되었다16).

1993년 신강성 문물고고연구소와 프랑스과학연구중심 135 연구소는 和田 县북쪽 약 $200 \mathrm{~m}^{2}$ 지점의 사막에서 喀拉弶 위진시기 불전유적 2기(N61, N62)를 발굴하였다. 벽체는 모두 “木骨泥墙法” 으로 축조되었으며 전체 평면은 “回” 자형으로 내부는 정방형 佛座기단과 4면은 통로로 이루어져 있 
으며 내외 벽체간의 거리는 $2 \mathrm{~m}$ 이다. 立佛과 솟⼸ㅇㅇㅢ 벽화 잔편들이 출토되 었다17).

2002년 10월 신강성 문물국, 신장성 문물고고연구소와 일본불교대학 尼 雅유적 학술연구기구가 공동으로 策勒县城 북쪽 약 $90 \mathrm{~m}^{2}$ 지점의 사막에서 불교사원유적(CD4)을 발굴하였다. 사원의 평면구조는 장방형이며 남북 길 이는 $8.2 \mathrm{~m}$, 동서 너비는 $6.02 \mathrm{~m}$ 이다. 벽체는 “木骨泥墙法”으로 축조되었으며 불상과 騎士 등의 벽화 잔편과 墨迹, 婆罗谜文题迹 등이 출토되었다. 이 사 원의 배치형태는 克里雅河喀拉墩 부근의 사원유적과 동일하고 초축년대는 5 세기이고 8세기 吐蕃의 于阗점령시기까지 사용되었다18).

2002년부터 2006년까지 중국사회과학원고고연구소는 신강 策勒县 达玛 沟乡 동남 약 $7 \mathrm{~m}^{2}$ 지점의 砂丘에서 托普鲁克墩불교사원유적을 발굴하였다. 1 호 유적은 소형의 불당유적이며, 남향으로 평면형태는 장방형이며 남북길 이는 $2 \mathrm{~m}$, 동서너비는 $1.7 \mathrm{~m}$ 이다. 불당 안 북쪽 벽에 붙어있는 覆蓮기단위에 소조불상이 위치하며 잔존 높이는 $1.45 \mathrm{~m}$ 이다. 4 면의 벽체에는 다량의 입불, 좌불, 보살 등의 벽화가 남아있다. 2호 유적은 동향으로 “回”자형의 불당구 조이다. 내부는 土坏를 사용하여 축조한 방형의 소조불상과 기단이 있다. 불당의 동쪽과 북쪽에는 각각 장방형의 측면 불당이 있으며 불두와 천불벽 화의 잔편, 비로자나불 목판화, 찰주, 擦擦, 五铢錢과 开元通宝등이 출토되 었다. 건축년대는 개원연간(713-741년)으로 추정된다. 2006년 达玛沟喀拉 墩 1호 불교유적에 대한 소규모 발굴이 진행되었으며 불두, 천수천안관음, 보살의 머리, 소형 좌불의 벽화잔편이 출토되었다. 또한, 광배부분의 벽화 잔편과 권초문 벽화잔편등이 출토되었으며 처음 축조시기는 7세기로 비정 된다19).

1979년 중국사회과학원 고고연구소는 신강 吉木萨尔县 北庭古城의 서쪽 에 위치한 高昌回鹘불교사원유적을 발굴하였다. 사원의 남쪽면과 동쪽면을 발굴조사하였으며 사원의 평면배치와 구조가 확인되었다. 사원의 평면형태 
는 장방형이며 바닥은 판축기단으로 지상은 모두 土坏를 이용하여 축조하였 다. 전체 유적은 남북 두 부분으로 구성되며 남쪽은 庭院, 配殿, 선방, 창고 등의 건축군이다. 북쪽은 잔존 높이 $14.3 \mathrm{~m}$ 의 정전이며 4 면은 동굴이 에워싸 고 있다. 불전 밖의 남면 상부에는 洞聋이 있으며 동쪽, 북쪽, 서쪽의 3 면 외벽에는 모두 2 층의 佛洞茏이 위치한다. 불전의 내부에는 불단을 설치 하여 불, 보살, 천왕, 나한상을 모시고 있으며 거대한 열반상도 하나 확인되 었다.

소조상은 당시에는 개금을 한 것으로 추정된다. 回鹘文題記에 “神圣的亦 都护”와 “长史”, “公主” 의 명문이 확인되는데, 이는 사원의 위상과 왕실과의 관계를 보여준다. 이 불교사원유적의 사용연대는 대체로 10 세기 중반에서 13세기 중반으로 추정된다. ${ }^{20)}$

중국불교는 유구한 역사를 가지고 있으며, 유적과 유물이 매우 풍부하다. 건축을 비롯하여 조상, 벽화, 문헌불경 등은 모두 연구의 대상이며 또한 중 국불교고고학연구의 대상 폭과 어려움을 보여준다. 최근 중국불교고고학 영 역에서 발표된 관련 논문들은 다양한 영역을 포괄하고 있어 단편적인 내용 으로는 전체를 포괄하기 어려운 점이 있다.

\section{(一) 석굴사고고학의 연구방법의 개선}

석굴사에 대한 고고학적 조사연구방법은 과거에는 주로 유형학적 방법론 을 사용하여 대조, 분류, 조합의 연구를 진행하였다. 그러나 1980년대부터 숙백선생을 중심으로 과거의 방법론에 대한 성찰과 새로운 모색이 시도되었 
다. 먼저 층위학적 방법론을 석굴사원의 조사와 연구에서 응용하여 석굴 불 감의 선후관계, 조상, 장식문양을 비롯하여 채색화의 교란관계를 분석하고 귀납하여 년대의 선후관계에 대한 신뢰할 수 있는 결론을 도출하였다. 그러 나 교란관계와 문화층의 선후관계는 상반관계이다. 즉 후기동굴에서는 초기 의 조상이 존재할 수 없으며 다만 초기의 遺風으로 남아있는 것으로 이해할 수 있다. 초기동굴에서는 후기의 補刻된 조각이 존재한다. 이는 운강석굴을 비롯한 석굴 연구에서 모두 응용되고 있다21). 다음으로 석굴사연구에서의 발굴조사의 중요성에 대한 인식이다. 지층에 대한 발굴을 통해 운강석굴에 서 북위, 당, 요금시기의 窟檐건축유적이 확인되었으며 龙门석굴 擂鼓台의 窟前유적에서 당대의 계단을 비롯하여 窟前殿堂의 포석기단, 송대의 造像題 記 및 당송시기의 도로등이 확인되었다. 이러한 성과들은 석굴사의 연혁과 분기, 시대구분에 모두 중요한 의미를 가지고 있다.

\section{(二) 塔基 地宮과 사리매장방식의 연구}

현재까지 중국에서 발굴된 불교사찰의 塔基는 상당수에 이른다. 주로 河 北定县北魏太和五年塔基、河南洛阳北魏故城永宁寺塔址、河北临漳县东魏 北齐佛寺塔址、河北定县隋静志寺塔基、陕西耀县隋神德寺舍利塔基、陕西 周至仙游寺法王塔、陕西西安隋唐青龙寺塔址、陕西扶凤唐法门寺塔址、陕 西临潼唐庆山寺塔基、甘肃云泾大云寺塔基、山西太原市太山唐龙泉寺塔基 등이 발견되어 연구자들의 관심과 연구를 불러일으켰다. 그 가운데 서평방 선생의 연구가 가장 권위 있는 연구업적에 속한다. 그는 《新中国的考古发 现和研究》, 《中国大百科全书·考古学》의 관련 항목과 《中国舍利塔基 考述》의 논문에서 1982년 이전의 중국사리탑기관련 고고학 자료를 광범위 하게 수집하여 체계적인 분석을 시도하여 중국사리탑기 및 사리매장기구의 
변화양상을 규명하였다. 그의 연구에 의하면 불탑은 심주 중심의 목탑에서 누각식, 혹은 密檐式 塼塔으로 변화하는 과정에서 塼石函과 유리병의 사용 에서 地宮과 金棺銀槨으로 사리의 매장방식이 변화하였음을 제시하였다. ${ }^{22)}$ 또한, 최근에는 일부 연구자들에 의해 서평방선생의 관점이 보충되기도 하였다. 23) 특히 최근 불탑탑기의 새로운 발견들은 기존 관점을 증명하여 주 고 있다.

\section{(三) 불교사원의 가람배치 연구}

중국에서 발견된 불교사원유적은 손에 꼽힐 정도이며 대체로 山西大同北 魏方山思远浮图遗址, 河南洛阳北魏故城永宁寺遗址, 河北临漳县啮城东魏北 齐佛寺遗址，陕西西安隋唐青龙寺遗址，陕西西安唐西明寺遗址，河南洛阳唐 奉先寺遗址등이 있다. 이러한 유적들은 平城思远浮图 외에는 모두 일부분 만이 발굴되었으며 대분분이 도성유적의 내부와 주변에서 위치한다.

1997년 숙백선생은 고고학자료에 근거하여 《东汉魏晋南北朝佛寺布局初 探》, 《隋代佛寺布局》의 두 논문을 발표하여 隋代 및 수대이전 불교사찰 가람배치에 대한 체계적인 연구를 시도하였다. 그는 5세기 북위의 낙양천도 이전 불교사원은 탑을 중심으로 강당, 선방등이 출현한다고 주장하였다. 아 울러 5세기에서 남북조의 멸망까지 일반적인 불교사원은 여전히 탑을 중심 으로 불탑이 불전의 전방에 위치하지만, 황실사원의 경우에는 別院山池 등 이 출현한다고 주장하였다. 수대의 불교사원은 여전히 앞 시기의 불탑 중심 의 전통적인 가람배치를 답습하고 있음을 주장하였다24).

당대에는 불교사원이 매우 발달하여 불교사원의 배치형태와 관련하여 연 구자들은 발굴자료와 돈황벽화, 문헌자료들을 종합하여 당대 불교사원의 가 람배치가 이미 불전 중심으로 전환되었음을 제시하였으며 아울러 불탑이 부 
차적인 지위의 多院落형식으로 전환되었음을 제기하였다25).

당대이후의 불교사원은 선종의 성행으로 선종사찰의 비중이 높아지면서 가람배치에서도 새로운 변화가 출현하여 伽藍七堂의 배치형태가 주류를 형 성한다26).

\section{(四 ) 장강유역의 기물에서 발견되는 불교도상과 불교의 남방전래에 대한 고찰과 연구}

1991년부터 중국 남경예술학원, 북경대학교, 남경박물관, 일본 용곡대학 은 공동으로 "초전불교의 남방루트" 과제를 추진하면서 연구팀은 모두 5차 에 걸쳐 장강유역에 따라 四川, 湖南, 湖北, 江苏, 广东등의 10 개 성, 시, 지 역을 대상으로 "초기불교조상의 남방전래"의 현장조사와 고찰을 진행하였다. 이후, 조사내용에 기초하여 《佛教初传南方之路》 출간하였는데, 이 도록에 는 반세기에 걸쳐 발견된 불상조형과 관련한 고고학 유적들이 수록되었다. 소개된 유물들은 대부분 다른 불교조형물에 조각되거나 그려진 (불교조형예 술품: 애묘부조의 석가불상, 摇钱树插座、铜钱树, 동한말기에서 위진시기

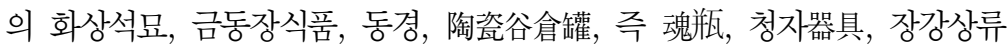
사천지역에서 볼 수 있는 钱树 및 애묘석각의 불상, 장강중류에서 출토된 유물에서 확인되는 青銅器, 즉 동경, 魂瓶의 불상은 장강하류의 절강지역 일 대에서만 볼 수 있다. 이러한 차이는 지역적인 차이)불상형상들이다. 그러나 이는 이후의 완전한 불교적 의미의 독립한 불교조상과는 구분된다. 단지 불 교적 함의를 내포한 형상으로 이해할 수 있으므로 佛의 형상으로 지칭되는 것이 합당하리라 생각된다. 이러한 조형은 남방에서만 확인되고 있으며 대 부분은 장강유역에서 발견되고 시기는 대체로 2-4세기에 속한다. 같은 시기 의 북방에서는 비슷한 예술품이 거의 발견되지 않았다. 그래서 이러한 불교 
예술품이 불교가 초기 중국 전파의 관계는 남방과 북방, 해상과 대륙 초기불 교가 중국에 전파된 과정에서의 지위와 역할 등의 문제도 나타났다. 불교가 초기에 전파된 시기, 남방과 서역은 다른 방식을 통하여 각각의 전파 방식에 따라 최초의 불교전파 근거지가 형성되었으며, 불교의 메시지가 중원에 전 파되었다. 따라서 불교가 중국에 전파되는 방법은 다원적이고, 대륙과 해상 은 초기불교가 중국에 전파되는 과정에서 그의 지위와 역할은 똑같다. ${ }^{27)}$

\section{(五) 석굴, 불상양식과 예술적 특징에 대한 연구}

석굴양식과 예술적 특징의 계승과 변천과정과 관련하여 숙백선생은 《ㄴ⿱⿱日小 州石窟遗迹与“凉州模式”， 《平城实力的集聚和“云冈模式”的形成与发展》 의 2 편의 논문을 발표하였다. 전자에서는 1994 년 天梯山석굴의 현지조사자 료를 통해 중국석굴이 天梯山석굴의 제 1 굴과 제 4 굴에서 기원하였음을 입증 하였다. 즉 초기의 北凉시기 동굴 또는 凉州석굴유적에 해당한다. 北凉 沮渠 蒙逊이 개착한 天梯山석굴이 바로 凉州석굴이며 이를 통해, "凉州模式"이 성 립되었다 (十六國시기 凉州는 불교문화의 중심지 이다).

县曜五窟을 포함한 운강석굴의 21 개 주요 동굴은 凉州 및 龟兹불교의 遺 風을 가지고 있다. 또한, 운강석굴을 모방한 용문석굴도 凉州석굴의 양식에 서 벗어나지 않는다. 후자의 논문헤는 운강석굴이 인도, 중앙아시아 등 여러 불교조상의 예술적 특징이 조합되어 성립된 것이며 이를 통해, "중국화"가 시작되었음을 주장하였다. 중기 석굴에서 출현하는 중국식 궁전건축양식의 조각, 중국식 佛像喻, 중국식 건축장식 등은 중국불교예술발전의 전환점이 된 "운강모식"이 형성되었음을 보여준다. 돈황 막고굴과 용문석굴의 북위시 기 조상은 대부분 운강석굴의 영향을 받았다28).

불상의 예술적 특징과 관련하여 숙백선생은 1999년 《근,城考略- - 青 
州城与龙兴寺之一》， 《龙兴寺沿革- - 青州城与龙兴寺之二》와 《青州龙 兴寺窑藏所出佛像的几个问题 - - 青州城与龙兴寺之三》을 발표하였다. 이 3편의 논문에서 용훙사조상의 예술적 특징은 동위 말기와 북제시기의 급격 히 변화에 원인한 것임을 지적하였다. "集衣博带式복식과 구분되는 불교조 상의 점진적 출현"으로 얇고 투명한 법의를 입은 불상은 青州風格의 다른 측면을 구현한 것이라 지적하였다. 이러한 예술적 특징을 가진 불상은 상투 가 살짝 나오고, 두 눈이 밑을 바라보고, 몸체가 날씬하고, 아름답고, 어께가 납작하고 넓다. 가슴은 살짝 나오며, 배가 살짝 나오고 허리는 날씬하고, 복 식이 가볍고 얇아 몸에 붙어 있으므로 “曹衣出水”의 효과가 잘 구현되었다. 보살상도 이와 같다. 이러한 "青州風格"은 주로 북제시기에 유행하였다29).

金维诺선생은 “曹家样”이 중앙아시아의 소구드(粟特)에서 기원하였으며 옷이 얇고 투명하고 "出水"와 동일한 양식으로 이해하였다. 河北曲阳修德寺, 山东青州龙兴寺에서 출토된 북조시 초기조상은 비교적 전형적인 "秀骨清像 式”으로 “青州样式”, 혹은 “薄衣式佛像”으로 지칭된다. 표면이 매끈하고 선 각이 간결하며 눈빛이 침착하고 자상하여 내재된 정신이 다양하다30). 상술 한 불상양식과 예술적 특징은 이 방면의 연구에 고리를 제공한다.

\section{(六) 능묘불사유적의 연구}

陵寺의 토론은 새로운 과제이다. 가장 먼저 능사에 주목하여 연구를 진행한 연구자는 白文固이다. 그는 《宋代的功德寺和坟寺》에서 "陵寺는 황능 옆의

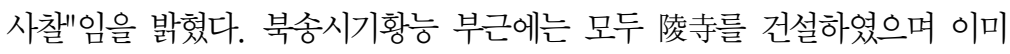
제도로 형성되었다. 이는 위진남북조시기까지 그 연원을 찾을 수 있다31).

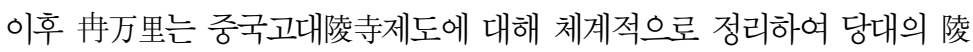
寺를 고증하였다. 그는 "중국고대왕릉의 능사제도는 그 연원을 남북조시기 에서 찾을 수 있으며 수당시기에 발전하여 북송시기에 성숙"하였다는 관점 
을 제시하였다. 북위 永固陵 앞에 위치한 思遠佛寺는 초기의 陵寺이다. 陵寺 는 황제능원 부근에 건립한 사원으로 황제릉의 부속 건축물이다. 일반적으 로 건립자는 대부분 후대 황제 또는 황실성원이며 일정한 목적이나 전통적 관습으로 전대의 황제를 위해 능사를 축조하거나 황제 본인이 황후를 위해 건립한 건물이기도 하다. 陵寺의 특수한 지리적 환경으로 인해 그 위상이 모두 높아 황실사찰에 속한다32). 张建林선생은 당대상장습관에 대한 연구 에서 당대의 ㅅ⿱⼢⼢에에 대해서도 다루고 있다33).

田有前은 당대昭陵부근에 위치한 瑶台寺와 高宗时期의 河北祖陵 부근의 光业寺, 中宗定陵附近의 定陵寺유적을 조사하고 건립년대, 위치, 기능에 대 해 서술하였다. ㅅ⿱⼢ㅇ에에 대한 고고학적 연구는 중국왕릉고고학 연구에서 중

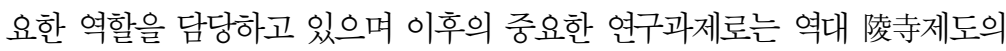
변화, 陵寺구역의 기본배치와 유적, 석각의 분포와 보존현황에 대한 문제등 을 들 수 있다34).

\section{(七) 불교석경에 대한 고고연구}

북제시기부터 명대까지 산동, 하남, 하북, 산시, 사천, 중경 등지의 불교도 들은 산의 절벽과 비석에 대규모의 불경을 다수 조각하여 후대에 귀한 문화 자산을 남겨주었다.

1957년 房山云居寺의 石經에 대한 발굴조사가 진행되어 석경연구를 시작을 알렸다35). 1978년 숙백선생은 제1기 석굴사고고 연구생에게 "佛典板本目錄"의 강의를 개설하여 房山云居寺석경을 포함하고 직접 현지조사를 실시하였다.

이후, 독일 海德堡대학 雷德侯교수를 위시한 학술단은 중국학자들과 공동 으로 각 지방에 산재한 석경에 대한 광범위한 조사를 진행하고 고고학과 미 술사의 연구방법을 종합적으로 적용하여 25년간 연구가 진행되었다. 그동안 
여러 차례에 걸쳐 국제학술대회를 개최하여 석경의 연구를 중국불교고고학 연구 중요한 내용으로 삼았다36).

\section{결론}

상기 내용을 종합하면 최근 중국불교고고학은 다양한 연구성과를 도출하

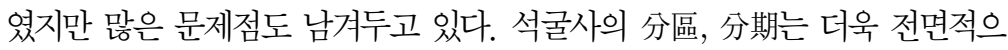
로 진행되어야 할 과제이다. 단일 지역 안 밖의 석굴사 사이의 관계와 석굴 사에 대한 종합적인 연구가 비교적 미약하다. 불사유적은 대부분 배치형태 만이 발굴조사되었으며 전면적인 발굴조사가 진행된 불사유적은 거의 없다. 불사유적에 대한 고고학 보고서도 많이 부족하여 연구자의 수요를 만족 시 키지 못하고 있다. 유구한 중국역사에 비해 불사유적이 많지 않은 점도 지 적할 수 있다. 국내외 불사에 대한 비교연구도 매우 산발적으로 진행되고 있다. 불교종파와 불사의 형식에 관한 연구도 아직 규명되지 않고 있다. 불 사와 도시, 鄉鎭과의 관계에 대한 연구도 과제로 남겨져 있다.

미래에 대한 전망에서 우리는 중국불교고고학의 발전에 대해 충만한 자 신감을 가지고 있다. 먼저, 선배들의 노력으로 이룩한 중국불교고고학의 체 계가 이미 형성되었으며 효과적인 이론과 연구방법론이 모색되고 있어 중국 고고학의 분과학문으로 자리매김하고 있다. 두 번째로 수십 년의 노력에 의 해 비교적 풍부한 고고자료가 이미 축척되어 이와 관련된 연구의 필요조건 이 제공되고 있다. 세 번째로 청년층과 중장년층으로 구성된 전문적인 연구 그룹이 형성되면서 학술교류의 공간이 만들어 졌다. 일부 청년연구자들은 이미 다양한 연구분야에서 중요한 학술적 위치를 맡아 과학연구의 주역이 되고 있다. 중국경제의 발전은 이와 관련한 시설과 연구경비의 지원에 뒷받 침이 되고 있다. 최근 불교유적에 대한 고고학조사는 한층 더 학계와 사회 
의 관심과 주목을 받고 있으며 조사와 발굴의 유적도 증가되면서 불교고고 학의 발전을 견인하고 있다. 관련연구는 더욱 세분화, 체계화, 과학화되고 있어 중국불교고고학의 발전의 전망은 낙관적이라 할 수 있다.

1）国家文物局编：《佛教石窟考古概要》，文物出版社，1993年。

2）李裕群《古代石窟寺》, 文物出版社，2003年。

3）盛春寿等：《阿艾石窟》，新疆美术摄影出版社，2001年。

4）《表一, 西安出土北周石刻佛教造像统计表》, 中国社会科学院考古研究所：《古都 遗珍长安城出土的北周佛教造像》, 文物出版社2010年; 《表二, 隋唐长安城佛寺遗 存一览》, 龚国强：《隋唐长安佛寺研究》, 文物出版社2006年。

5）中国社会科学院考古研究所著《北魏洛阳永宁寺 - - 1979 - 1994年考古发掘报告》, 中国大百科全书出版社 1996年。

6）大同市博物馆胡平：《大同北魏方山思远佛寺遗址发掘报告》，《文物》2007年4期。

7）夏名采《青州龙兴寺佛教造像窑藏，》生活. 读书. 新知三联书店2004年。

8）中国社会科学院考古研究所、河北省文物研究所：《河北临漳县业城遗址东魏北齐佛 寺塔基的发现与发掘》，《考古》2003年10期 ; 中国社会科学院考古研究所、河北 省文物研究所斨城考古队：《河北临漳县攸城遗址赵彭城北朝佛寺遗址的勘探与发 掘》，《考古》2010年第7期 ; 中国社会科学院考古研究所：《河北临漳县业城遗址 北吴庄佛教造像埋藏坑的发现与发掘》, 《考古》2012年4期 ; 中国社会科学院考古 研究所、河北省文物研究所：《河北业城遗址赵彭城北朝佛寺及北吴庄佛教造像埋藏 坑》，中国文物信息网2013年03月28日。

9）刘景龙、李永强：《络阳龙门奉先寺遗址发掘简报》，《中原文物》2001年2期。

10）成都市文物考古研究所、工崃市文物管理局：《四川扔崃龙兴寺-2005-2006年考古发 掘报告》文物出版社2011年。

11）中国社会科学院考古研究所：《唐长安青龙寺遗址》，《考古学报》1989年2期。

12）中国社会科学院考古研究所：《唐长安西明寺遗址发掘简报》, 《考古》1990年1期。

13）中国社会科学院考古研究所、内蒙古第二工作队、内蒙古文物考古研究所：《内蒙古 巴林左旗辽上京皇城西山坡佛寺遗址考古获重大发现》，《考古》2013年 第1期。

14）中国社会科学院考古研究所：《六顶山与渤海镇》, 中国大百科辞典出版社1997年。

15）《西藏萨迦寺考古发掘再获重要成果》，《2007年中国重要考古发现》，文物出版社 2008年。

16）中日共同尼雅遗迹学术考察队：《中日共同尼雅遗迹学术调查报告书》卷2, 中村印 刷株式会社，1999年；张铁男、王宗否：《95年尼雅遗址93A35佛教寺院发掘简 报》、《1996年尼雅93A35号遗址中FA、FB、FC、FD发掘简报》，分别载于《新 疆文物》1998年第1期、1999年第2期。 
17）中法联合克里雅河考古队：《新疆克里雅河流域考古考察概述》，《考古》1999年第 7 期。

18）中国新疆文物考古研究所、日本佛教大学尼雅遗址学术研究机构：《丹丹乌里克遗 址中日共同考察研究报告》, 文物出版社2009年 ; 刘国瑞、屈涛、张玉忠：《新疆 丹丹乌里克遗址新发现的佛寺壁画》，《西域研究》2005年4期；盛春寿、李军、 张铁男等: 《新疆丹丹乌里克遗址新发现的佛寺壁画》, 《边疆考古研究》第七 辑, 2008年。

19）中国社会科学院考古研究所新疆队：《新疆和田地区策勒县达玛沟佛寺遗址发掘报 告》，《考古学报》2007年第4期。

20）中国社会科学院考古研究所：《中国田野考古报告集：北庭高昌回鹘佛寺遗址》, 辽宁美术出版社，1991年。

21）杭㑆：《云冈第二十窟西壁佣埸的时间与县曜五窟最初的布局设计》，《文物》 1994年10期。

22）徐苹芳：《中国舍利塔基考述》，《中国历史考古学论丛》，台北允晨文化1995年。

23）杨泓：《法门寺塔基发掘与中国古代舍利痤埋制度》， 《文物》1988年10期。

24）宿白：《东汉魏晋南北朝佛寺布局初探》, 《庆祝邓广铭教授九十华诞论文集》, 河北教育出版社，1997年；宿白：《隋代佛寺布局》, 《考古与文物》1997年2期。

25）萧默：《敦煌建筑研究》, 文物出版, 1989年; 梁思成：《敦煌壁画中所见的中国 古代建筑》，《梁思成文集》(一), 中国建筑工业出版社1982年 ; 龚国强 ; 《隋唐 长安佛寺研究》, 文物出版社2006年; 周绍良主编：《梵宫-一中国佛教建筑艺 术》, 上海辞书出版社2006年。

26）戴俭：《禅宗寺院建筑布局初探》，台北明文书局1990年。

27）梁白泉等：《佛教初传南方之路》, 文物出版社, 1993年; 阮荣春：《佛教南传之 路》, 湖南美术出版社, 2000年。

28）宿白：《凉州石窟遗迹和 “凉州模式”》，《考古学报》1986年第4期；宿白：《平 城实力的集聚和 “云冈模式” 的形成与发展》, 《中国石窟・云冈石窟》 (一), 文 物出版社，1991年。

29）宿白：《青州城考略—- 青州城与龙兴寺之一》, 《文物》1999年第8期； 《龙兴寺 沿革一青州城与龙兴寺之二》, 《文物》1999年第9期 ; 《青州龙兴寺窝藏所出佛 像的几个问题 - - 青州城与龙兴寺之三》, 《文物》1999年第10期。

30）金维诺：《中国古代佛雕：佛造像样式与风格》, 文物出版社2002年。

31）白文固：《宋代的功德寺和坟寺》, 《青海社会科学》2000年5期。

32）舟万里：《帝陵建寺之制考略》，《西部考古》第一辑，三秦出版社，2006年。

33) 张建林： 《唐代丧葬习俗中佛教因素的考古学考察》, 《西部考古》第一辑, 三秦出 版社， 2 006年。

34）田有前：《唐代陵寺考》，《文博》2010年第4期。

35）中国佛教协会编：《房山云居寺石经》，文物出版社1978年版。

36）罗炤：《中国佛教考古学的开创者一宿白先生九秩华诞献词》, 《石窟寺研究》第 三辑，文物出版社2012年。 